IZA DP No. 8945

Wage Setting in the Colombian Manufacturing Industry

Sonia A. Agudelo

Hector Sala

March 2015 


\title{
Wage Setting in the Colombian Manufacturing Industry
}

\author{
Sonia A. Agudelo \\ Universitat Autònoma de Barcelona \\ Hector Sala \\ Universitat Autònoma de Barcelona \\ and IZA
}
Discussion Paper No. 8945
March 2015

\author{
IZA \\ P.O. Box 7240 \\ 53072 Bonn \\ Germany \\ Phone: +49-228-3894-0 \\ Fax: +49-228-3894-180 \\ E-mail: iza@iza.org
}

\begin{abstract}
Any opinions expressed here are those of the author(s) and not those of IZA. Research published in this series may include views on policy, but the institute itself takes no institutional policy positions. The IZA research network is committed to the IZA Guiding Principles of Research Integrity.

The Institute for the Study of Labor (IZA) in Bonn is a local and virtual international research center and a place of communication between science, politics and business. IZA is an independent nonprofit organization supported by Deutsche Post Foundation. The center is associated with the University of Bonn and offers a stimulating research environment through its international network, workshops and conferences, data service, project support, research visits and doctoral program. IZA engages in (i) original and internationally competitive research in all fields of labor economics, (ii) development of policy concepts, and (iii) dissemination of research results and concepts to the interested public.
\end{abstract}

IZA Discussion Papers often represent preliminary work and are circulated to encourage discussion. Citation of such a paper should account for its provisional character. A revised version may be available directly from the author. 


\section{ABSTRACT}

\section{Wage Setting in the Colombian Manufacturing Industry*}

We show that wage setting in the Colombian manufacturing industry is not fundamentally driven by labor productivity in contrast to the standard theoretical prediction. On the contrary, internal institutional arrangements - payroll taxation, the minimum wage or the price wedge between manufacturing and consumption prices - together with a higher exposure to international trade - connected to the increasing globalization of the Colombian economy appear as the crucial drivers. These findings lead us to question the political strategy followed to attain cost competitiveness in a context of growing exposure to international trade. Implementation of a true wage bargaining system is suggested as a critical policy target to prevent the disruptive economic consequences of the current wage setting mechanism and help rebalance the trade deficit.

JEL Classification: J30, F16, J31

Keywords: $\quad$ wage setting, labor productivity, trade openness, payroll taxes, minimum wages, price wedge

Corresponding author:

Hector Sala

Department d'Economia Aplicada

Universitat Autònoma de Barcelona

08193 Bellaterra

Spain

E-mail: hector.sala@uab.es

\footnotetext{
* We acknowledge helpful comments from Pedro Trivín on earlier versions of this paper. Sonia A. Agudelo and Hector Sala are grateful for financial support received, respectively, from COLCIENCIAS and the Spanish Ministry of Economy and Competitiveness (grant ECO2012-13081).
} 


\section{Introduction}

Two structural and worldwide phenomena are critically shaping policy decisions. The first one is globalization. The second one, going in parallel, is a deindustrialization process taking place in many countries. Globalization implies a growing exposure to international trade that needs to be strategically handled bearing in mind the specific strengths and weaknesses of the economy in change. The manufacturing industry is the most exposed economic activity, hence the need of a careful design of the policies that will allow industrial activities to cope.

On this account, Colombia provides an excellent experience to examine. It is one of the considered successful economies in Latin America which, in recent decades, embarked in an extensive liberalization program. The issue we assess here is whether this extensive program has been translated into an efficient mechanism of wage determination, at least at the industrial level. Our conclusion is that it has not. And the reason is twofold. First, because of the low connection between wages and productivity; and, second, because of the failure of the policy reforms to set up a true wage bargaining system and enhance the connection between wages and productivity.

We study wage setting in the Colombian manufacturing industry in a period in which relatively tight labor market and trade regulations in the seventies and eighties have been superseded by more flexible labor market institutions and trade liberalization. We investigate, in particular, which are the crucial drivers of net real wages with explicit focus on the role played by labor productivity, the changing institutional framework, and the growing exposure to international trade. This analysis is conducted through the estimation of a standard wage setting model using a panel database which covers a long time period (1974-2009) and 19 manufacturing sectors. This estimation involves the consideration of several type of interactions to disclose whether the institutional and trade reform process has affected the way wages respond to its driving forces.

In this context, a first salient result is the permanent low sensitivity of net real wages to changes in labor productivity. In other words, labor productivity is not the fundamental driver of the net real wage, is in sharp contrast with the standard theoretical prediction of a one-to-one long-run relationship between wages and labor productivity (see Judzik and Sala, 2013, for the simplest analytical case). The reason why this theoretical relationship is far from holding in the Colombian manufacturing industry is twofold. First, the adjustments of nominal wages are highly tied to the cost of living. Second, payroll taxes and other non-wage costs make up a significant part of total compensation. Both features weaken the sensitivity of net real wages to changes in labor productivity. A sensitivity that has even decreased after the institutional and trade reform process. 
In contrast to the scarce influence of productivity, we find wages to be mainly driven by internal institutional settings (such as payroll taxation and minimum wages), other determinants related to the indexation of wages with respect to prices (such as the price wedge between manufacturing and consumer prices), and openness to trade. As we explain later, the real minimum wage and the price wedge can be considered two sides of the same coin capturing the close attachment of wages to the evolution of prices (with real minimum wages growing according to prices).

This leads us to specify the empirical model under two alternative settings, one with the real minimum wage and another one with the price wedge, revealing a high sensitivity of net real wages to changes in both the real minimum wage and the price wedge (depending on the specification). This result provides empirical evidence that the adjustments of nominal wages are highly tied to the cost of living, which is critically driving the growth of net real wages in the manufacturing industry. A specific feature of this result is the absence of a significant change in the wage reaction to these driving forces, with similar elasticities in 1976-1991 and 1992-2009.

The third main finding is the significant negative impact of payroll taxation on net wages. Two are the reasons by which payroll taxes may cause a fall in net real wages. The first one is to avoid an increase in total labor costs: firms try to lower net nominal wages to compensate the increase in payroll taxation and, therefore, there is a change in the composition of labor costs in response to the higher tax rates. The second mechanism consists in shifting the increase in payroll taxation to selling prices to try to keep the profitability rates unchanged. This, however, was not feasible in Colombia in a situation of growing exposure to international trade.

The impact of payroll taxes on wages has been lower after 1992 in spite that most of the increases in these taxes (paid by firms) took place in this period. That is, although the payroll tax shifting continued to be significant, firms started bearing a larger share of the payroll tax cost. This result provides evidence that some of the changes in the institutional environment have harmed the cost competitiveness of the industrial sector.

In this context, the explanation of the lower sensitivity of real wages to payroll taxation is twofold. First, the enhanced indexation of nominal wages to Consumer Price Index (CPI) inflation caused net real wages to be more responsive to the price wedge (with severe downward pressures on manufacturing prices resulting from the liberalization process) and less to payroll taxes. Second, it was gross wages, rather than net wages, who absorbed the bulk of the impact of the payroll tax rise (note that the gap between the growth rates of gross and net wages tripled from 0.21 to 0.65 percentage points, as shown in Table 2).

The last finding is the significant positive impact of globalization on wages in 19761991 and 1992-2009, and the slightly greater influence they have exerted in the second 
period. This positive and greater influence is interpreted along the lines of Arbache et al. (2004), who point to the skill-biased nature of in-flowing technology (through higher foreign direct investment and growing imports) to explain the greater demand of skilled labor, and the resulting pressure on relative wages.

In the light of these results, we conduct a complementary exercise in which we examine the marginal effects of real minimum wages and the price wedge on net real wages, conditional on the different values taken by payroll taxation and the degree of trade openness. In this way, we check whether the reform process (that is, the increases in payroll taxation and the exposure to international trade) have affected the way wages react to these key determinants. We find no difference in the extent of the wage impact of real minimum wages across periods, which remained stable in spite of the liberalization process; this does not preclude, however, that more open sectors tend to be less responsive to changes in the minimum wage. In turn, the sensitivity of real wages to the price wedge becomes larger along with the degree of trade openness in a scenario of high payroll taxation such as the one in 1992-2009. This response is clearly different than the one in 1976-1991, and calls for future research on the interaction between wages, payroll taxes and trade exposure.

The rest of the paper is structured as follows. Section 2 reviews some key features of the Colombian economy regarding the institutional setting and the trade liberalization process. Section 3 discusses the theoretical background on wage setting models, and their empirical implementation in the paper. Section 4 presents the data and explains the econometric methodology. Sections 5 and 6 deal with the results. Section 7 concludes.

\section{Labor market institutions and trade liberalization}

\subsection{Labor market reforms}

The Colombian labor market is segmented. There is a massive informal sector accounting for around $50 \%$ of employment, and a formal sector accounting for the remaining $50 \%{ }^{1}$ Within this context, the manufacturing industry is an economic activity with a relatively low incidence of informality close to $20 \%{ }^{2}$

Since 1990, a structural reform process has been developed in view, on one side, to enhance labor market flexibility and boost (formal) employment and expand, on the other side, the coverage of health and pension services.

\footnotetext{
${ }^{1}$ Value for thirteen metropolitan areas in year 2013 computed from data provided by the Gran Encuesta Continua de Hogares (GEIH).

${ }^{2}$ It was $18.7 \%$ in 2007 , in contrast to close to $75.0 \%$ in trade and services (values based on data for thirteen metropolitan areas supplied by the GEIH).
} 
To achieve the first target, Law 50 was passed in 1990 to lower firing, training and recruitment costs, and promote non-regular forms of employment. This was followed by Law 789 in 2002, which lowered the regulated costs of non-standard employment (for example, on weekend, night, and holiday working hours). The expectation was that such measures would contribute to render formal employment more attractive and boost job creation.

To expand the coverage of health and pension services, Laws 100 in 1993 and 797 in 2003 were passed to increase the Social Security revenues needed to expand the fledgling welfare state. The first of these laws increased the payroll tax rates covering the health and pension schemes, while the second one only focused on pensions. In this way, the total payroll tax rate paid by firms moved from the existing $17 \%$ before these laws, to more than $30 \%$ since the mid nineties, and beyond afterwards. Figure 1 shows this evolution by distinguishing the four components in which payroll taxes are classified in Colombia: parafiscal, health, pension and professional hazards. ${ }^{3}$

Figure 1. Payroll taxes paid by firms. 1975-2009.

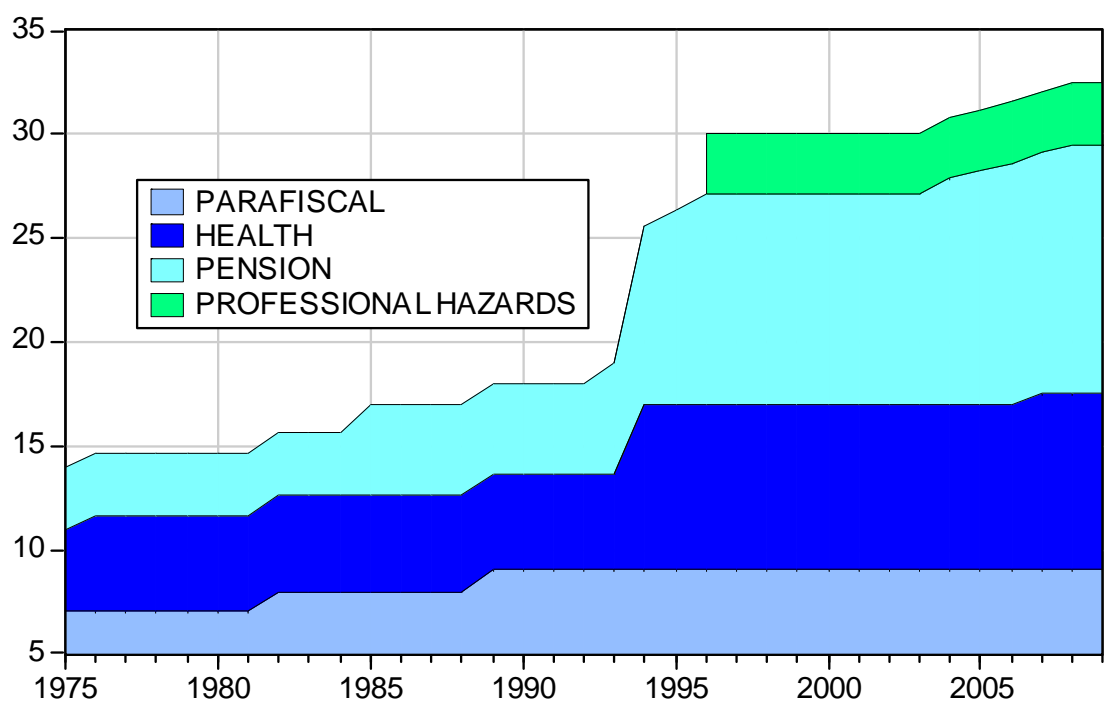

Source: Own calculation based on data from LEGIS' official annual reports. ${ }^{4}$

There is ample literature on institutions referring to the supposedly 'labor-unfriendly' impact of payroll tax rate increases. This common view may be one of the reasons why,

\footnotetext{
${ }^{3}$ The parafiscal contributions are payroll taxes which are only paid by firms. They have been used to finance the Family Compensation System, the National Service of Learning (SENA by its acronym in Spanish) and the Colombian Family Welfare Institute (ICBF by its acronym in Spanish). The health and pension payroll taxes correspond to contributions that firms and employees must shell out in a traditional social security system. The professional hazards are payroll taxes paid by firms that have been used to fund the General System of Occupational Risks, whose aim is to protect and assist workers from the effects of diseases and accidents that may befall them during or as a result of their work. In this study we take into account all payroll taxes paid by firms.

${ }^{4}$ Cartilla Laboral, years 1989-2009; and Cartilla de la Seguridad Social, years 1990-2009.
} 
without hardly any assessment on the estimated consequences of the previous measures, the government decided to lower first (by Law 1429 of Formalization and employment generation in 2010), and then eliminate, the parafiscal and health contributions paid by firms (by Law 1607 in 2012).

One exception in the virtual lack of assessment of the consequences of the rise in payroll taxes in Colombia is the work by Kugler and Kugler (2009). Their results show that a $10 \%$ increase in payroll taxes reduces wages of production workers by $1.46 \%$, wages of nonproduction workers by $2.75 \%$, production employment by $5.14 \%$, and nonproduction employment by $4.38 \% .^{5}$

Another critical labor market institution is the minimum wage. Although the government had the power to set a minimum wage since 1945 (by Law 6), it was in 1949 when it was effectively implemented for the first time. The minimum wage is indexed on a yearly basis following the previous year CPI inflation rate. Its growth cannot be inferior to this rate, ${ }^{6}$ which is the same irrespective of the economic sector (see Hofstetter, 2005, for details).

In practice, it turns out that the real minimum wage operates as a sort of reservation wage which not only is a floor wage (in levels), but also a reference for wage increases in formal activities. Hence their strong correlation, as shown in Figure 2.

Figure 2. Real wages of the manufacturing industry 1975-2009.

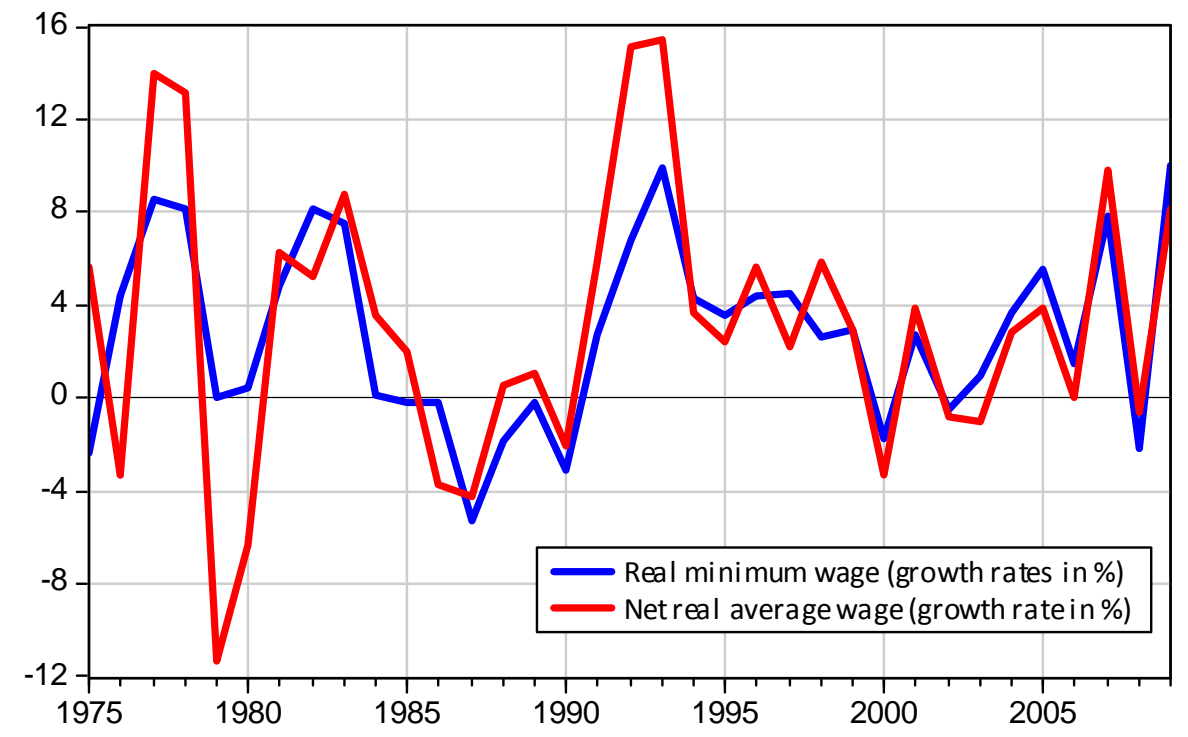

Source: EAM for the net real wage and legislation published annually for the minimum wage.

\footnotetext{
${ }^{5}$ Production workers (or employment) include workers in tasks strictly related to productive activities (usually called blue-collar), while nonproduction workers (or employment) include workers in administrative tasks (usually called white-collar). This is the distinction made by Kugler and Kugler (2009) because of the source data they work with.

${ }^{6}$ This was started by judgment C-815 of the Constitution Court in 1999 as a consequence of the loss of purchasing power of the minimum wage in the eighties and early nineties.
} 
Finally, although the Colombian labor legislation recognizes unions as a part of the labor relations system, its role in wage-setting matters is nowadays minimal and essentially restricted to collective bargaining at the firm-level. Union density in Colombia is around $4 \%$, while the coverage of collective agreements is less than $2 \%$ (data from ENS).

\subsection{Trade reforms}

In parallel to the labor market reform process, Colombia also embarked in a process of external liberalization in the 1990s. The first step in this process took place unilaterally in 1990, when the political authorities increased the Colombian exposure to international trade by reducing, simultaneously, import controls and import tariffs. In this way, free imports (i.e., custom non-controlled imports) rose from $14.8 \%$ in 1985 to $96.7 \%$ in 1990 , while the average customs duty rate was reduced from $38.9 \%$ in 1990 to $12.0 \%$ in 1995 .

In addition, between 1992 and 2004, Colombia enjoyed a new system of preferential tariffs to export to the US. ${ }^{7}$ This system was superseded in 2004 by Free Trade Agreements (FTAs) between Colombia and a number of relevant trade partners such as the US, the European Union, Canada, Mexico, Korea, Chile, Salvador, Guatemala and Honduras.

As a consequence, trade openness (i.e., the ratio of exports plus imports over GDP) increased from below 25\% in 1990 to more than 40\% today (Figure 3a). Therefore, although Colombia is still considered a relatively closed economy, in the last two decades it experienced a significant change in its overall degree of globalization as measured, for example, by the KOF index (Figure 3b). From a value of $34.3 \%$ in 1975, this index only increased by 4 percentage points up to 1990 (34.2\%). The steep slope thereafter reflects the liberalization process of the Colombian economy, leading the KOF index to reach 57\% in 2009.

In this context, the manufacturing industry has been the most affected sector in Colombia, with a steady increase in the imports share that attained $90 \%$ of total Colombian imports in 2009 (see Figure A1a in the Appendix), and a share of exports above $60 \%$ of total exports, in contrast to a share of less than $15 \%$ in terms of GDP. Still more important, trade openness in this sector (i.e., the ratio of industrial exports and imports over total industrial output) doubled from an average of $48.2 \%$ in $1974-1991$, to one of $96.8 \%$ in $1992-2009 .^{8}$

\footnotetext{
${ }^{7}$ The APTA was signed in December 1991. Through this agreement around 5,600 products were granted free access to the US market in exchange of a renewed focus on economic activities and jobs aiming at replacing the cocaine industry. This agreement was subsequently prolonged and extended, 2002 onwards, through the APTDEA.

${ }^{8}$ Detailed information by sectors is provided in the Appendix. All industries, but one (publishing and printing recorded media, just accounting for around 3\% of total industrial GDP) were subject to this process, and there are no significant composition effects within the manufacturing industry in Colombia: the GDP share of the largest sector (on food products and beverages) remained stable at 28-29\%, while
} 
Figure 3. Globalization in Colombia. 1974-2009.

a. Trade openness

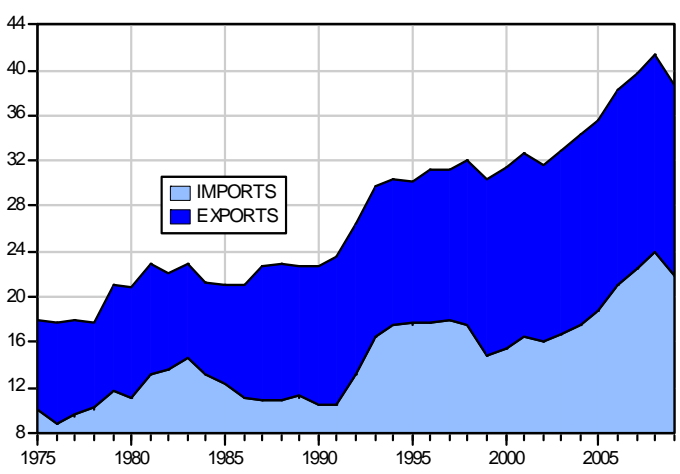

b. KOF index

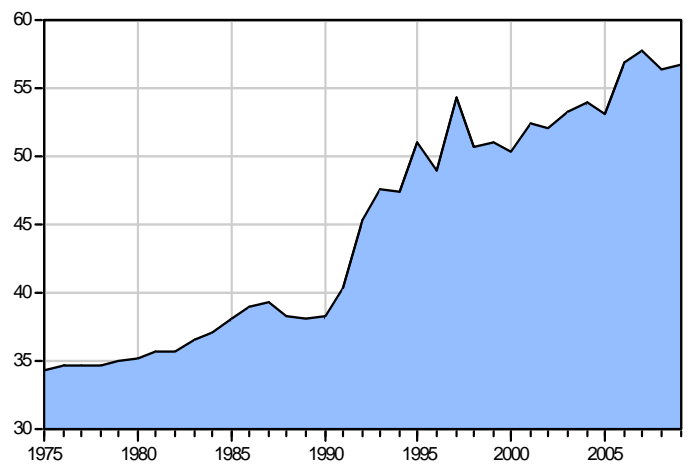

Source: DANE for Trade openness; Dreher et al. (2008) for the KOF index.

A related critical issue is that the leading role played by the manufacturing sector in the opening process of Colombia has been accompanied by a large deterioration of its international competitiveness. This is illustrated in Figure A1b, which shows a structural trade deficit that became much larger on averages since the nineties.

\section{$3 \quad$ Wage setting}

\subsection{Theoretical background}

Standard wage setting models have been developed both in perfect and imperfect competition contexts.

A relevant example of a perfect competition wage setting model can be found in Kugler and Kugler (2009), where the market-clearing wage and employment levels are set to equate the demand and supply of labor. Firms choose employment by equating the gross marginal labor costs - net wage plus payroll taxes- with the marginal revenue of producing an extra unit of output. In turn, workers set their labor supply as a function of net wages and their prospective social security benefits received in exchange of the payroll tax paid by firms. This gives form to the tax/benefit linkage developed in Summers (1989). The outcome of this model is that wages are set as a function of the labor demand and labor supply elasticities with respect to wages, and also with respect to the payroll tax (paid by firms) and the valuation made by workers over the benefit received.

In a context of imperfect competition, the traditional classification distinguishes efficiency wage from collective bargaining models such as the insider-outsider or union models -Lindbeck and Snower (2001), Booth (2014). Within this vast strand of literature, the

the five largest sectors (S1, S3, S12, S10 and S9 in Table A1) accounted for $62.2 \%$ the industrial GDP in the first period, and $65.9 \%$ in the second one. 
work by Prodecca (2011) provides an encompassing model in which a large number of identical unions and firms set real wages in a Nash bargaining framework. Empirically, her model states that the real wage is related to the following six fundamental variables: labor productivity $(Y / N)$, the unemployment rate $(u)$, the replacement ratio $(B R R)$, union bargaining strength $(\eta)$, payroll taxes/non-wage costs $\left(\tau^{p}\right)$, and income taxes $\left(\tau^{i}\right)$.

By solving the theoretical model in a Cobb-Douglas framework and log-linearizing the resulting expression, Prodecca (2011) obtains her core empirical equation:

$$
\begin{aligned}
\log \left(W_{t}\right)= & a_{0}+a_{1} \log \left(Y_{t /} / N_{t}\right)-a_{2} \log \left(u_{t}\right)+a_{3} \log \left(B R R_{t}\right) \\
& +a_{4} \log \left(\eta_{t}\right)+a_{5} \log \left(\tau_{t}^{p}\right)+a_{6} \log \left(\tau_{t}^{i}\right)+\varepsilon_{t}
\end{aligned}
$$

To study the Colombian case, this benchmark expression needs to be adapted at least for a twofold reason. First, because some institutional features that are generally considered as crucial in developed economies, are less relevant in Colombia. Consequently, we lack times series information to be included in the analysis. Second, because the benchmark model we have considered does not account for the role of the external sector which, as we have discussed, is likely to have affected wage determination in the manufacturing industry. On top of these reasons, some data is simply not available.

Therefore, we next discuss the adjustments and extensions we introduce to the benchmark equation (1).

\subsection{Empirical implementation}

The first adjustment relates to the replacement ratio, which is essentially nonexistent in Colombia as a source of income for unemployed. There is a related in-kind benefit which was to a large extent improperly used (not as a true unemployment benefit) before the 2013 reform. This affects the term $a_{3} \log \left(B R R_{t}\right)$, which is dropped from the analysis. ${ }^{9}$

The second adjustment refers to union power in whatever form (measures of trade union density, number of strikes, or days lost due to labor conflicts). Although there is data since the 1990s, any measure related to union power was not relevant as explanatory variable in subsample regressions conducted for 1992-2009. This is the reason why the term $a_{4} \log \left(\eta_{t}\right)$ is omitted.

A final adjustment is the exclusion of $a_{6} \log \left(\tau_{t}^{i}\right)$ due to the lack of information on income taxes in consistent time series. One problem is that effective tax rates are not

\footnotetext{
${ }^{9}$ At this point, it is worth noting that although a system of unemployment benefits exists in Colombia since 2002 (by Law 789), it had to be restructured in 2013 to enforce its use in correspondence to its nature. This implies, in contrast to the emphasis placed by the literature on the wage impact of such benefits, that the unemployment benefit system in Colombia has been irrelevant as a determinant of wage setting.
} 
available. The other problem is that using the statutory rates would not be accurate given the features of our panel data. The reason is that the income tax scheme sets differentiated rates by income group, with low incomes subject to tax exemptions. Therefore, as we only have data on average wages across sectors, the use of statutory tax rates could distort the true effect of income taxation on wages.

The central institutional extension is the inclusion of the real minimum wage, which acts as a reference for real wages. This implies considering the new term $a_{2} \log \left(W_{t}^{\min }\right)$, where $W_{t}^{\min }$ denotes the real minimum wage. A positive sign on $\hat{a}_{2}$ is expected.

This extension is consistent with the findings in Iregui et al. (2012), who show that nominal minimum wage increases and past inflation are considered as important factors by firms when adjusting their nominal wages. Their analysis also reveals that most firms adjust nominal wages annually at rates that are roughly equivalent to the observed rate of CPI inflation, and none of them cut wages.

A second extension is related to relative prices and seeks to capture the role exerted by the price wedge between manufacturing and total prices in wage setting. The variable we consider is $\pi_{t}$, the ratio of manufacturing prices $\left(p_{t}^{m}\right)$ over consumption prices $\left(p_{t}^{c}\right)$, and we expect a negative influence over net real wages. The reason is the following. Over time, manufacturing prices tend to grow less than consumption prices for a twofold reason. First, it is a capital-intensive sector subject to quick technological change and efficiency gains that are translated into lower prices (or higher quality at equal prices). Second, it is the most exposed sector to global competition and, as such, bears the most important downward pressure on prices. This forces firms to use labor compensation as a key adjustment mechanism to ensure competitiveness. In this context, given that nominal wages in Colombia are indexed to the CPI, the larger is the wedge between the two, the bigger is the tension in terms of the wage setting mechanism: while workers grade their net wages having as reference consumption prices, firms appraise their expected benefits as a function of manufacturing prices. Here is the wedge and the tension pushing real net wages down when the wedge increases.

An important remark here is that the real minimum wage and the price wedge can be considered two sides of the same coin capturing the close attachment of wages to the evolution of prices. The reason is the following. If nominal minimum wages are closely tied to consumption prices, then the ratio $\left(W_{t}^{\min } / p_{t}^{m}\right)$ will not differ that much in its evolution from the price ratio $p_{t}^{c} / p_{t}^{m}$, which is the inverse of our price wedge variable $p_{t}^{m} / p_{t}^{c}$. Having confirmed this empirically, our empirical models will take two alternative forms to avoid multicollinearity problems, one with the real minimum wages as explanatory variable, as in equation (2) below; and a second one considering the price wedge instead: equation (3).

A final extension is related to the external sector and consists on the inclusion of a 
measure of trade openness $(o p)$ through the addition of the new aggregate term $a_{4} \log (o p)$. The expected incidence of international trade, or globalization, on net wages is not clear. On one side, the literature is still far from reaching consensus on the causal relationship between exports and productivity (and thus wages). Some relevant studies argue that exports cause efficiency gains (and would thus boost wages), while some other claim that efficiency progress is what allows exports to increase.

In the case of Colombia, we have two pieces of information that make us look at the imports' side. First, exports have not led the opening process (see Figure 3a). Second, as shown by Figure A1a in the Appendix, the share of manufacturing exports has remained stable between 1965 and 2010. Hence, if the industrial imports of goods are the catalyst variable, then we should expect a positive influence on net wages for a twofold reason. ${ }^{10}$

First, on account of the positive relationship between wages and the import of intermediate goods, as demonstrated in Amiti and Davis (2011). This hypothesis is endorsed by the fact that two thirds of total industrial imports in Colombia consist on intermediate inputs. And second because, as pointed out by Arbache et al. (2004), one of the consequences of increasing trade openness is a rapid inflow of foreign technology as a result both of foreign direct investment and increased imports. In-flowing technology is skillbiased because it is mainly designed in industrialized economies which are relatively skill intensive. Thus, the acquisition of new technologies from developing countries is normally accompanied by a greater demand of skilled labor. On the positive side this causes an upward pressure on relative wages (which is the effect we are capturing), although there is also a negative consequence in terms of increased wage inequality. ${ }^{11}$

Overall, these empirical adjustments and extensions leave us with two versions of the empirical model. In the first version, we have the real minimum wages:

$\log \left(W_{t}\right)=a_{0}+a_{1} \log \left(Y_{t /} / N_{t}\right)+a_{2} \log \left(u_{t}\right)+a_{3} \log \left(W_{t}^{\min }\right)+a_{4} \log \left(\tau_{t}^{p}\right)+a_{5} \log \left(o p_{t}\right)+\varepsilon_{t}$,

while in the second version we have the ratio of manufacturing prices over consumption prices:

$$
\log \left(W_{t}\right)=a_{0}+a_{1} \log \left(Y_{t /} / N_{t}\right)+a_{2} \log \left(u_{t}\right)+a_{3} \log \left(\pi_{t}\right)+a_{4} \log \left(\tau_{t}^{p}\right)+a_{5} \log \left(o p_{t}\right)+\varepsilon_{t}
$$

\footnotetext{
${ }^{10}$ Relevant studies claiming a negative relationship between imports and local wages point to massive imports of consumption goods in developed economies. For example, for the United States, Autor et al. $(2013,2014)$ show that wages/cumulative earnings were lower after the spectacular rising of the Chinese imports, mainly of consumption goods.

${ }^{11}$ Growing empirical evidence on the effects of globalization gives support to a positive relationship between trade liberalization and wage inequality in developing countries -see, for example, Caselli (2014), Meschi and Vivarelli (2009), and Attanasio et al. (2004).
} 
To conclude, note that all coefficients will have to be interpreted as delivering elasticities. It is in this context that we treat payroll taxes as the tax wedge between gross and net wages.

\section{Empirical issues}

\subsection{Data}

We use a panel database with a cross-section dimension of $N=19$ sectors and a time dimension of $T=34$ years covering the period $1976-2009 .{ }^{12}$ Table 1 presents the variables and the corresponding sources.

Net average real wages per worker are obtained from the Annual Manufacturing Survey (Encuesta Anual Manufacturera, EAM), which is produced by the National Administrative Department of Statistics (Departamento Administrativo Nacional de Estadística, DANE). It is calculated as the real wage bill before taxes in sector $i$ over paid employment in that sector. Labor productivity is computed as the real value added in sector $i$ over total employment in that sector, where total employment includes paid and unpaid workers. It is also obtained from the EAM. As explained above, trade openness is computed as exports plus imports in sector $i$ over output in that sector. It is also obtained from the EAM. Note that these are the three variables for which detailed homogeneous time series information across sectors exists.

As stated, informal employment in Colombia is massive. This goes together with very limited statistics covering labor issues in non-urban areas. Consequently, the unemployment rate series available for the whole sample period is based on urban unemployment. Although it does not exactly fit the industrial sector, this is the only one we can use.

Data on nominal minimum wages is collected from public information/legislation published annually. Similarly, the statutory payroll tax rates (including health, pension, professional hazards, and parafiscal contributions) are computed from information supplied by LEGIS in its official annual reports. Note, therefore, that we use statutory rates instead of any sort of effective tax rate. In this way, we avoid dealing with econometric problems related to the use of effective tax rates, namely the simultaneity in the determination of wages and payroll tax rates, and spurious variability in payroll tax rates. In turn, the number of national strikes is obtained from the national trade union institution (Escuela Sindical Nacional, ENS). Note, however, that this variable is only available from 1992 onwards and can only be used for the second part of the sample.

\footnotetext{
${ }^{12}$ The detailed list of sectors is provided in Table A1, in the Appendix.
} 
Manufacturing prices and the CPI index are also taken from the DANE. These two indices are used to compute the ratio of relative prices.

Table 1. Definitions of variables.

\begin{tabular}{|c|c|c|c|c|}
\hline \multicolumn{2}{|c|}{ Variables } & \multirow{2}{*}{$\begin{array}{c}\text { Sources } \\
(1)\end{array}$} & \multicolumn{2}{|c|}{ Other variables and subindices } \\
\hline$W_{i t}$ & Net real wage & & $d^{92}$ & Dummy: value 11992 onwards \\
\hline$Y_{i t}$ & Real GDP & (1) & $d^{8083}$ & Dummy: value 1 in $1980-1983$ \\
\hline$N_{i t}$ & Total employment & (1) & $d^{9700}$ & Dummy: value 1 in $1997-2000$ \\
\hline$\frac{Y_{i t}}{N_{i t}}$ & labor productivity & (1) & $d^{0809}$ & Dummy: value 1 in 2008-2009 \\
\hline$o p_{i t}$ & Trade openness $\left[\frac{(\text { exports }+ \text { imports })_{i t}}{\text { output }_{i t}}\right]$ & $(1)$ & $i$ & $=1, \ldots, 19$ sectors \\
\hline$u_{t}$ & Urban unemployment & $(2)$ & $t$ & $=1, \ldots, 34$ years \\
\hline$W_{t}^{\min }$ & Real minimum wage & $(3)$ & & \\
\hline$\tau_{t}^{p}$ & Statutory payroll tax rates & $(4)$ & & \\
\hline$p_{t}^{m}$ & Manufacturing prices & $(2)$ & & \\
\hline$p_{t}^{c}$ & CPI deflator & $(2)$ & & \\
\hline$\pi_{t}$ & Relative prices $\left[\frac{P^{m}}{P^{c}}\right]$ & $(2)$ & & \\
\hline
\end{tabular}

Notes: All nominal variables are deflated by the manufacturing price index (base: June 1999).

(1) EAM; (2) DANE; (3) Legislation published annually; (4) LEGIS.

We include a set of time dummies to control for macroeconomic shocks that may affect all sectors. In this way, $d^{92}$ help us to capture potential structural breaks in the wage elasticities arising from the institutional and trade reform process; $d^{8083}$ accounts for the impact of the international debt crisis experienced by Latin America in the early eighties; $d^{9700}$ and $d^{0809}$ checks whether the international financial crisis at the end of the nineties and the Great Recession did also affect wages in Colombia.

All nominal variables are deflated with the manufacturing price index.

\subsection{Stylized facts}

Table 2 provides descriptive information on some crucial macroeconomic variables of interest. Subscript $i$ denotes information corresponding to the average of the 19 sectors in which the Colombian industry is disaggregated. Detailed industry information is not available for the real minimum wage, manufacturing prices, the CPI index, and the payroll tax rate. All data is supplied for the two relevant periods of analysis - the slow transition between import substitution and trade liberalization in 1976-1991; and the institutional and trade reforms years of 1992-2009.

Since the mid-seventies until 2009, real economic growth of the Colombian manufacturing sectors was around $4.2 \%$ on average, with no significant differences between periods. 
In spite of these positive growth rates throughout, the industrial standstill in the seventies and the debt crisis in the eighties resulted in low employment growth rates $(0.3 \%$ on average in 1976-1991) and, thus, in high labor productivity growth rates (3.8\% on average). In contrast, gross wages (i.e., the addition of net wages and statutory payroll taxes) grew at $2.1 \%$, thus prompting an annual fall in the unit labor costs of $1.7 \%$ on average. Note also, that net real wages (payroll taxes excluded) and real minimum wages grew in line (at around $1.9 \%$ ) reflecting highly tied adjustments to the cost of living. These years were also characterized by high inflation rates, amounting to $22.5 \%$ if measured by the CPI, and $21.5 \%$ by manufacturing prices. As a consequence, the price wedge went down by 1 percentage point annually, on average.

Table 2. Macro developments in the Colombian manufacturing industry.

\begin{tabular}{|c|c|c|c|c|c|c|}
\hline & $\gamma_{Y_{i t}}$ & $\gamma_{N_{i t}}$ & $\gamma_{Y_{i t} / N_{i t}}$ & $\gamma_{W_{i t}}$ & $\tau_{t}^{p}$ & $\gamma_{\left[W_{i t}\left(1+\tau_{t}^{p}\right)\right]}$ \\
\hline 1976-1991 & 4.16 & 0.31 & 3.85 & 1.94 & 16.1 & 2.13 \\
\hline $1992-2009$ & 4.30 & -0.30 & 4.60 & 3.85 & 28.9 & 4.50 \\
\hline \multirow[t]{2}{*}{ 1976-2009 } & 4.23 & 0.70 & 3.53 & 2.99 & 23.1 & 3.42 \\
\hline & $\gamma_{W_{t}^{\min }}$ & $\gamma_{p_{t}^{m}}$ & $\gamma_{p_{t}^{c}}$ & $\gamma_{\pi_{t}}$ & $o p_{i t}$ & $\gamma\left[\frac{W_{i t}\left(1+\tau_{t}^{p}\right)}{Y_{i t} / N_{i t}}\right]$ \\
\hline $1976-1991$ & 1.86 & 21.5 & 22.5 & -0.97 & 48.4 & -1.72 \\
\hline 1992-2009 & 3.59 & 9.0 & 11.2 & -2.23 & 96.8 & -0.10 \\
\hline $1976-2009$ & 2.80 & 14.9 & 16.5 & -1.64 & 74.0 & -0.11 \\
\hline
\end{tabular}

Notes: $\gamma$ denotes the growth rate corresponding to the annual average of the sectorial growth rates. All variables are expressed in percent.

The nineties were years of labor reform and trade liberalization processes, but also of deindustrialization and growing expansion of the services sector. They were followed, though, by the recovery of the manufacturing sector in 2000-2009 driven by a rising capital accumulation (boosted both by domestic and foreign direct investment) ${ }^{13}$ and the substitution of domestic by imported raw materials. Altogether, these developments caused employment to fall (by $0.30 \%$ annually, on average) and resulted in the acceleration of the growth rate of labor productivity $(4.6 \%)$, which was 0.8 percentage points larger than in 1974-1991. In turn, gross real wages grew in line with productivity $(4.5 \%$ on average), thus denying further progress in real unit labor costs. Beyond productivity gains, it should be noted that upward pressures on gross real wages arose from increases in payroll taxes paid by firms, and from the acceleration in the increase of the price wedge,

\footnotetext{
${ }^{13}$ In the seventies and eighties, FDI represented $0.3 \%$ of the GDP on average, while between 1997 and 2007 it represented 3.8\%. Source: DANE.
} 
reflecting the speedier deceleration of inflation in manufacturing prices than in the cost of living.

These contrasted periods, both in terms of economic developments and policy agenda (as discussed in Section 2), lead us to the estimation of equations (2) and (3) taking into account potential changes in the elasticities brought by the new institutional framework. As we explain next, this estimation is conducted by considering several types of dummies and interactions among selected explanatory variables.

\subsection{Econometric methodology}

Empirical equations (2) and (3) are extended in two directions. First, due to the relevance of adjustment costs in wage setting, we consider the addition of the first lag of the explanatory variable. This enables us to perform a dynamic analysis and to compute shortand long-run effects of each explanatory variable on net real wage. Second, as we work with a two-dimensional panel data, we add fixed effects in order to control for unobserved heterogeneity among sectors.

Given the dynamic nature of the extended models, equations (2) and (3) will be estimated as partial adjustment models taking the following general form:

$$
\ln \left(W_{i t}\right)=\alpha_{i}+\gamma \ln W_{i t-1}+\beta \ln X_{i t}+u_{i t}, \quad u_{i t} \sim i i d\left(0, \sigma_{i}^{2}\right)
$$

where the subscripts $i$ and $t$ are sector and time indices, respectively; $\alpha_{i}$ is a sectorial cross-section intercept; $W_{i, t-1}$ is the lagged dependent variable with $\gamma$ as inertial (or persistence) coefficient; $X$ is a vector of explanatory and control variables with $\beta$ as the set of estimated parameters capturing their influence on the dependent variable $W_{i t}$; and $u_{i t}$ is the error term.

\subsubsection{Unit root tests}

As we deal with a dynamic panel, we must ensure that a long-run equilibrium relationship exists among the variables considered. This implies testing that all variables are stationary $I(0)$ which, by definition, yields a long-run cointegrating vector.

In order to check the order of integration of the variables, we perform a set of stationary and panel unit root tests depending on the type of variables to be dealt with. In particular, we use the Kwiatkowski, Phillips, Schmidt and Shin (1992) stationary-test -KPSS henceforth- for the variables that are common across sectors. For the variables that are sector-specific, we use the test proposed by Maddala and Wu (1999) - MW-, 
which is a panel unit root test based on Fisher's (1932) results. ${ }^{14}$ The MW test assumes, under the null hypothesis, that all series are non-stationary, against the alternative that at least one series in the panel is stationary. We use the KPSS test because it allows direct testing of the null hypothesis of stationarity.

Table 3. Unit Root Tests, 1974-2009.

\begin{tabular}{|c|c|c|c|c|c|c|c|c|}
\hline \multicolumn{4}{|c|}{ Different variables across sectors } & \multicolumn{5}{|c|}{ Common variables across sectors } \\
\hline & $W_{i t}$ & $Y_{i t} / N_{i t}$ & $o p_{i t}$ & & $W_{t}^{\min }$ & $\pi_{t}$ & $\tau_{t}^{p}$ & $u_{t}$ \\
\hline \multicolumn{4}{|c|}{ Null hypothesis: individual unit root process } & \multicolumn{5}{|c|}{ Null hypothesis: variable is stationary } \\
\hline MW & $\begin{array}{c}134.43 \\
{[0.000]}\end{array}$ & $\begin{array}{c}111.74 \\
{[0.000]}\end{array}$ & $\begin{array}{l}50.55 \\
{[0.084]}\end{array}$ & KPSS & $\begin{array}{c}0.08 \\
{[0.146]}\end{array}$ & $\begin{array}{c}0.08 \\
{[0.146]}\end{array}$ & $\begin{array}{c}0.09 \\
{[0.146]}\end{array}$ & $\begin{array}{c}0.07 \\
{[0.146]}\end{array}$ \\
\hline Result & $\mathrm{I}(0)$ & $\mathrm{I}(0)$ & $\mathrm{I}(0)$ & Result & $\mathrm{I}(0)$ & $\mathrm{I}(0)$ & $\mathrm{I}(0)$ & $\mathrm{I}(0)$ \\
\hline
\end{tabular}

Notes: All variables are expressed in logs; MW and KPSS tests computed using intercept and trend; for the MW test, p-values in brackets; for the KPSS test, $5 \%$ critical values in brackets.

On the other hand, we conduct the MW test because, in general, panel-based unit root tests have higher power than unit root tests when applied to individual time series. Moreover, this test has two attractive characteristics. First, it does not restrict the autoregressive parameter to be homogeneous across sectors under the alternative of stationarity. Second, the choice of the lag length and the inclusion of a time trend in individual ADF test regressions can be determined separately for each sector.

As noted in the last row of Table 3, the overall conclusion drawn from these tests is that all variables are stationary $I(0)$. Hence, we can proceed with stationary panel data estimation techniques.

\subsubsection{Estimation method}

Given the panel structure of our database, models (2) and (3) are estimated by applying Ordinary Least Square (OLS) and Fixed Effects (FE). In doing so, we need to take care of potential endogeneity problems caused by the introduction of lagged dependent variables in the set of regressors; by the well-known simultaneity between net real wages, labor productivity, and unemployment; and by the potential correlation between relative prices and the error term, on account of the simultaneity of wage and price setting.

Regarding the first potential problem, it is well known that OLS estimates gives rise to a "dynamic panel bias" (Nickell, 1981) causing the persistence coefficient to be overestimated. The reason is that the estimated coefficient on lagged wages will be inflated by attributing some predictive power to it that actually belongs to the sector's fixed effect.

\footnotetext{
${ }^{14}$ Using Monte Carlo simulations, Maddala and Wu (1999) conclude that the Fisher test is a better test than the Levin and Lin (1993) and the Im, Pesaran and Shin (2003) tests. They also highlight that the Fisher test is simple and straightforward to use.
} 
A potential response would then be to apply the within-groups (or fixed effects) estimator, but this does not fully offset the dynamic panel bias. This was explained by Nickell (1981), who pointed out, also, that when $T$ is large and $N$ is small $(T>N)$, this bias is likely to be insignificant. In contrast, Judson and Owen (1999) found that even with a time dimension as large as 30, this estimator would be downward biased and inconsistent even in the absence of serial correlation in the error term.

Although this may not be a critical problem in our analysis (we have $T=34$ and $N=19$ ), we can not fully exclude the existence of a dynamic panel bias. We have thus estimated different versions of the Least Squares Dummy Variables Corrected (LSDVC) using Bruno's (2005) approximation to correct for the finite-sample bias. The corresponding results, presented in the Appendix (Table A2), show that these sets of estimates do not differ and allow us to conclude that the FE estimator is potent in our case.

We have not compute the System GMM estimator (Blundell and Bond, 1998), which is a common option to deal with dynamic panel biases. The reason is that the consistency of this estimator depends on the fact that $N \rightarrow \infty$ grows sufficiently fast relative to $T$. Since this is not the case here, the estimation by System GMM would not yield dramatic consistency gains over the FE estimator; not to mention the instrument proliferation problem, which emerges even we limit and collapse the massive amount of instruments due to the number of potentially endogenous regressors in our empirical models.

Thus, to deal with the potential endogeneity of labor productivity, the price wedge and unemployment, we estimate FE by Two Stage Least Squares (FE-2SLS), where the instruments are lags and differences of the explanatory variables. To select the most appropriate set of instruments we rely on the performance of the following sets of tests. First, an LM test checking for underidentification (i.e., that the excluded instruments are not relevant, meaning non correlated with the endogenous regressors). This is denoted as $U$ in Tables 5 and A3, and the null hypothesis is that the equation is underidentified (against the alternative that the model is identified). Second, the Hansen test of overidentifying restrictions (denoted as $H$ ), in which the joint null hypothesis is, on one side, that the considered instruments are valid (i.e., uncorrelated with the error term) and, on the other side, that the excluded instruments are correctly dropped from the estimated equation. Third, an $F$ test checking for weak identification (denoted as $W$ ), where the null hypothesis is that the instruments are correlated with the endogenous regressors, but only weakly. ${ }^{15}$

\footnotetext{
${ }^{15}$ Note that for this test we do not show the critical values (since the standard ones of Stock and Yogo, 2005, are not available), and we follow "the rule of thumb" of suggested by Staiger and Stock (1997) in such cases: an $F$-statistic near or above 10.
} 


\section{Results}

Tables 4 and 5 present, respectively, the estimated short- and long-run elasticities obtained through the various estimation methods just discussed: OLS (in columns 1 and 5) displayed as a reference to check whether the persistence coefficients obtained by the other methods are lower, as expected; FE (in columns 2 and 6); and FE-2SLS (in columns $3,4,7$ and 8$)$.

In the specification presented in column 3, we consider labor productivity and the respective interaction as weakly exogenous. By so doing, we use as instruments lags and differences (the first lag and the difference of the third lag for labor productivity, and just the first lag for the interaction term). In the specification of column 4, we also consider unemployment and their interaction with the dummy variable as weakly exogenous, and use the first lag in both cases. Regarding the specifications presented in columns 7 and 8 , we keep these assumptions and further consider the price wedge and its interaction as endogenous, having their second lag as instrument. ${ }^{16}$

All this information is classified in two blocks, the one on the left-hand-side corresponding to the estimation of equation (2) and the one on the right-hand-side to equation (3).

To these benchmark empirical models we add interactions between dummy and explanatory variables so as to capture potential structural changes related to the Colombian institutional reform process. Accordingly, we next overview the results, and place some attention on the stability, or not, of the estimated elasticities between 1976-1991 and 1992-2009.

\subsection{Wage setting before the reform process (1976-1991)}

When examining the econometric analysis, if we have to favor some particular specification, we would choose the results in columns 4 and 8 for a three-fold reason: (i) instrumental variables are used to deal with potential endogeneity problems; (ii) the performance of the instrumental variable tests confirm the appropriateness of the instruments in most cases (since they are simultaneously exogenous and highly correlated with the endogenous regressors); and (iii) all variables have the expected sign according to the underlying theoretical relationships.

In any case, the four sets of estimates (i.e., those presented in columns 3 and 4 in the left block, and those in columns 7 and 8 in the right block) provide a similar picture

\footnotetext{
${ }^{16}$ It is worth noting that we have estimated a wide set of specifications using different combinations of instruments depending on whether we consider labor productivity, unemployment and the price wedge either as weakly exogenous variables or endogenous. However, we only present those specifications with the best performance in the instrumental tests.
} 
with significant effects on net wages of labor productivity, the real minimum wage, the price wedge and payroll taxes, all displaying the expected sign. In contrast, the role of trade openness is found mildly significant and not very strong, while the evidence on the unemployment rate is mixed.

Regarding the first model, results in column 4 display a short-run elasticity of wages with respect to labor productivity of 0.32 (Table 5) increasing to $44 \%$ in the long-run (Table 6) but still far away from unity, which is the theoretical benchmark value. Since only $44 \%$ of productivity gains are translated into a higher net compensation of workers ( $32 \%$ initially), wage setting in the Colombian manufactory industry is not fundamentally driven by labor productivity. This leaves space for other potentially more relevant determinants related to institutional arrangements (such as payroll taxation and minimum wages) and other determinants related to the indexation of wages with respect to prices (again the minimum wage or, alternatively, the price wedge), which will turn out to be crucial wage setting drivers.

The short-run elasticity of wages with respect to the real minimum wage is estimated at 0.95, increasing to 1.30 in the long-run. This captures the upward pressure that minimum wages exert on wages and implies that a $1 \%$ increase in the real minimum wage causes net real wages to grow by $1.30 \%$ ( $0.95 \%$ initially). The counterpart of this result is provided in column 8 , in which the real minimum wage is replaced by the price wedge. We find that the short-run elasticity of wages with respect to relative prices is -3.12 , increasing to -5.80 in the long-run. This implies that a $1 \%$ increase in the ratio of manufacturing prices over consumption prices cause wages to decrease by $5.80 \%$ overall ( $3.12 \%$ initially). In other words, from this alternative specification, we are able to gauge to what extent manufacturing firms are forced to reduce wages to regain competitiveness when prices of manufacture goods become relatively more expensive (and vice-versa).

Regarding payroll taxation, the short-run coefficient of -0.94 increases to -1.30 in the long-run. This implies that $94 \%$ percentage of the tax burden is immediately shifted to workers in the form of lower net wages, which further decrease in the long-run. This is the outcome of the direct and indirect effects of payroll taxes on labor market outcomes: they have a negative impact on the labor demand (on account of the extra labor cost they represent for employers), but they also decrease net real wages and generate a compensation effect. Which effect dominates crucially depends on wage persistence. In case of significant wage persistence (and hence a large long-run effect), wage compression may overcome the direct negative effects on employment generated by payroll taxation. 
Table 4. Estimated wage equations.

\begin{tabular}{|c|c|c|c|c|c|c|c|c|}
\hline \multicolumn{9}{|c|}{ Dependent variable: $W_{i t}$} \\
\hline & \multicolumn{4}{|c|}{ MODEL I } & \multicolumn{4}{|c|}{ MODEL II } \\
\hline & OLS & $\mathrm{FE}$ & FE-2SLS & FE-2SLS & OLS & FE & FE-2SLS & FE-2SLS \\
\hline & (1) & $(2)$ & $(3)$ & $(4)$ & $(5)$ & (6) & (7) & $(8)$ \\
\hline$W_{i t-1}$ & $\begin{array}{c}0.79 \\
{[0.000]}\end{array}$ & $\begin{array}{c}0.42 \\
{[0.001]}\end{array}$ & $\begin{array}{c}0.25 \\
{[0.094]}\end{array}$ & $\begin{array}{c}0.27 \\
{[0.080]}\end{array}$ & $\begin{array}{c}0.82 \\
{[0.000]}\end{array}$ & $\begin{array}{c}0.54 \\
{[0.000]}\end{array}$ & $\begin{array}{c}0.45 \\
{[0.002]}\end{array}$ & $\begin{array}{c}0.46 \\
{[0.002]}\end{array}$ \\
\hline$Y_{i t} / N_{i t}$ & $\begin{array}{c}0.08 \\
{[0.000]}\end{array}$ & $\begin{array}{c}0.03 \\
{[0.363]}\end{array}$ & $\begin{array}{c}0.33 \\
{[0.020]}\end{array}$ & $\begin{array}{c}0.32 \\
{[0.015]}\end{array}$ & $\begin{array}{c}0.07 \\
{[0.000]}\end{array}$ & $\begin{array}{c}0.03 \\
{[0.382]}\end{array}$ & $\begin{array}{c}0.27 \\
{[0.041]}\end{array}$ & $\begin{array}{c}0.23 \\
{[0.067]}\end{array}$ \\
\hline$u_{t}$ & $\begin{array}{c}-0.12 \\
{[0.025]}\end{array}$ & $\begin{array}{c}-0.15 \\
{[0.000]}\end{array}$ & $\begin{array}{c}-0.05 \\
{[0.215]}\end{array}$ & $\begin{array}{c}-0.15 \\
{[0.318]}\end{array}$ & $\begin{array}{c}-0.01 \\
{[0.696]}\end{array}$ & $\begin{array}{c}0.04 \\
{[0.257]}\end{array}$ & $\begin{array}{c}0.11 \\
{[0.035]}\end{array}$ & $\begin{array}{c}0.18 \\
{[0.001]}\end{array}$ \\
\hline$W_{t}^{\min }$ & $\begin{array}{c}0.38 \\
{[0.000]}\end{array}$ & $\begin{array}{c}0.69 \\
{[0.000]}\end{array}$ & $\begin{array}{c}0.78 \\
{[0.000]}\end{array}$ & $\begin{array}{c}0.95 \\
{[0.000]}\end{array}$ & & & & \\
\hline$\pi_{t}$ & & & & & $\begin{array}{l}-1.37 \\
{[0.000]}\end{array}$ & $\begin{array}{l}-1.46 \\
{[0.000]}\end{array}$ & $\begin{array}{l}-2.37 \\
{[0.000]}\end{array}$ & $\begin{array}{l}-3.12 \\
{[0.000]}\end{array}$ \\
\hline$\tau_{t}^{p}$ & $\begin{array}{c}-0.40 \\
{[0.001]}\end{array}$ & $\begin{array}{c}-0.24 \\
{[0.000]}\end{array}$ & $\begin{array}{c}-0.90 \\
{[0.026]}\end{array}$ & $\begin{array}{c}-0.94 \\
{[0.012]}\end{array}$ & $\begin{array}{c}-0.40 \\
{[0.000]}\end{array}$ & $\begin{array}{c}-0.13 \\
{[0.038]}\end{array}$ & $\begin{array}{c}-0.74 \\
{[0.034]}\end{array}$ & $\begin{array}{c}-0.82 \\
{[0.010]}\end{array}$ \\
\hline$o p_{i t}$ & $\begin{array}{c}0.01 \\
{[0.015]}\end{array}$ & $\begin{array}{l}0.00 \\
{[0.703]}\end{array}$ & $\begin{array}{c}0.08 \\
{[0.112]}\end{array}$ & $\begin{array}{c}0.08 \\
{[0.117]}\end{array}$ & $\begin{array}{c}0.01 \\
{[0.038]}\end{array}$ & $\begin{array}{c}0.00 \\
{[0.598]}\end{array}$ & $\begin{array}{c}0.06 \\
{[0.152]}\end{array}$ & $\begin{array}{l}0.05 \\
{[0.155]}\end{array}$ \\
\hline$d_{92}$ & $\begin{array}{c}-0.40 \\
{[0.509]}\end{array}$ & $\begin{array}{c}0.16 \\
{[0.717]}\end{array}$ & $\begin{array}{c}0.41 \\
{[0.272]}\end{array}$ & $\begin{array}{c}1.09 \\
{[0.332]}\end{array}$ & $\begin{array}{c}0.26 \\
{[0.534]}\end{array}$ & $\begin{array}{c}0.61 \\
{[0.034]}\end{array}$ & $\begin{array}{c}-1.54 \\
{[0.106]}\end{array}$ & $\begin{array}{c}-1.61 \\
{[0.009]}\end{array}$ \\
\hline$W_{i t-1} * d_{92}$ & $\begin{array}{l}0.13 \\
{[0.005]}\end{array}$ & $\begin{array}{c}0.14 \\
{[0.027]}\end{array}$ & $\begin{array}{c}0.48 \\
{[0.000]}\end{array}$ & $\begin{array}{c}0.46 \\
{[0.000]}\end{array}$ & $\begin{array}{c}0.11 \\
{[0.019]}\end{array}$ & $\begin{array}{c}0.10 \\
{[0.103]}\end{array}$ & $\begin{array}{c}0.35 \\
{[0.002]}\end{array}$ & $\begin{array}{c}0.32 \\
{[0.012]}\end{array}$ \\
\hline$Y_{i t} / N_{i t} * d_{92}$ & $\begin{array}{c}-0.05 \\
{[0.032]}\end{array}$ & $\begin{array}{c}-0.04 \\
{[0.342]}\end{array}$ & $\begin{array}{c}-0.25 \\
{[0.000]}\end{array}$ & $\begin{array}{c}-0.24 \\
{[0.000]}\end{array}$ & $\begin{array}{c}-0.04 \\
{[0.072]}\end{array}$ & $\begin{array}{c}-0.02 \\
{[0.492]}\end{array}$ & $\begin{array}{c}-0.20 \\
{[0.004]}\end{array}$ & $\begin{array}{c}-0.17 \\
{[0.024]}\end{array}$ \\
\hline$u_{t} * d_{92}$ & $\begin{array}{c}0.05 \\
{[0.345]}\end{array}$ & $\begin{array}{c}0.12 \\
{[0.003]}\end{array}$ & $\begin{array}{c}-0.01 \\
{[0.862]}\end{array}$ & $\begin{array}{c}0.05 \\
{[0.769]}\end{array}$ & $\begin{array}{c}0.03 \\
{[0.347]}\end{array}$ & $\begin{array}{c}0.03 \\
{[0.417]}\end{array}$ & $\begin{array}{c}-0.11 \\
{[0.203]}\end{array}$ & $\begin{array}{c}-0.17 \\
{[0.053]}\end{array}$ \\
\hline$W_{t}^{m i n} * d_{92}$ & $\begin{array}{c}-0.05 \\
{[0.695]}\end{array}$ & $\begin{array}{c}-0.13 \\
{[0.123]}\end{array}$ & $\begin{array}{c}-0.46 \\
{[0.003]}\end{array}$ & $\begin{array}{c}-0.59 \\
{[0.034]}\end{array}$ & & & & \\
\hline$\pi_{t} * d_{92}$ & & & & & $\begin{array}{c}0.11 \\
{[0.650]}\end{array}$ & $\begin{array}{l}-0.01 \\
{[0.970]}\end{array}$ & $\begin{array}{l}1.30 \\
{[0.002]}\end{array}$ & $\begin{array}{c}1.79 \\
{[0.011]}\end{array}$ \\
\hline$\tau_{t}^{p} * d_{92}$ & $\begin{array}{c}0.08 \\
{[0.555]}\end{array}$ & $\begin{array}{c}0.10 \\
{[0.223]}\end{array}$ & $\begin{array}{c}0.66 \\
{[0.057]}\end{array}$ & $\begin{array}{c}0.72 \\
{[0.033]}\end{array}$ & $\begin{array}{c}-0.29 \\
{[0.028]}\end{array}$ & $\begin{array}{c}-0.41 \\
{[0.000]}\end{array}$ & $\begin{array}{c}0.16 \\
{[0.627]}\end{array}$ & $\begin{array}{c}0.17 \\
{[0.423]}\end{array}$ \\
\hline$o p_{i t} * d_{92}$ & $\begin{array}{c}-0.01 \\
{[0.049]}\end{array}$ & $\begin{array}{c}-0.02 \\
{[0.028]}\end{array}$ & $\begin{array}{c}-0.04 \\
{[0.047]}\end{array}$ & $\begin{array}{c}-0.04 \\
{[0.045]}\end{array}$ & $\begin{array}{c}-0.01 \\
{[0.108]}\end{array}$ & $\begin{array}{c}-0.01 \\
{[0.108]}\end{array}$ & $\begin{array}{c}-0.03 \\
{[0.093]}\end{array}$ & $\begin{array}{c}-0.03 \\
{[0.093]}\end{array}$ \\
\hline$d_{8083}$ & $\begin{array}{c}-0.03 \\
{[0.172]}\end{array}$ & $\begin{array}{c}-0.06 \\
{[0.000]}\end{array}$ & $\begin{array}{c}-0.06 \\
{[0.000]}\end{array}$ & $\begin{array}{c}-0.08 \\
{[0.001]}\end{array}$ & $\begin{array}{c}-0.02 \\
{[0.195]}\end{array}$ & $\begin{array}{c}-0.02 \\
{[0.092]}\end{array}$ & $\begin{array}{c}-0.02 \\
{[0.145]}\end{array}$ & $\begin{array}{c}-0.02 \\
{[0.105]}\end{array}$ \\
\hline$d_{9700}$ & $\begin{array}{l}0.02 \\
{[0.047]}\end{array}$ & $\begin{array}{c}0.01 \\
{[0.062]}\end{array}$ & $\begin{array}{l}0.02 \\
{[0.051]}\end{array}$ & $\begin{array}{c}0.03 \\
{[0.028]}\end{array}$ & $\begin{array}{c}-0.03 \\
{[0.000]}\end{array}$ & $\begin{array}{c}-0.05 \\
{[0.000]}\end{array}$ & $\begin{array}{c}-0.02 \\
{[0.363]}\end{array}$ & $\begin{array}{c}-0.03 \\
{[0.068]}\end{array}$ \\
\hline$d_{0809}$ & $\begin{array}{c}-0.04 \\
{[0.029]}\end{array}$ & $\begin{array}{c}-0.02 \\
{[0.259]}\end{array}$ & $\begin{array}{c}-0.02 \\
{[0.177]}\end{array}$ & $\begin{array}{c}-0.03 \\
{[0.076]}\end{array}$ & $\begin{array}{c}-0.06 \\
{[0.000]}\end{array}$ & $\begin{array}{c}-0.04 \\
{[0.103]}\end{array}$ & $\begin{array}{c}-0.05 \\
{[0.047]}\end{array}$ & $\begin{array}{c}-0.06 \\
{[0.074]}\end{array}$ \\
\hline$c$ & $\begin{array}{c}-0.58 \\
{[0.195]}\end{array}$ & $\begin{array}{c}-0.46 \\
{[0.341]}\end{array}$ & & & $\begin{array}{c}2.49 \\
{[0.029]} \\
\end{array}$ & $\begin{array}{c}4.37 \\
{[0.259]} \\
\end{array}$ & & \\
\hline Obvs. & 646 & 646 & 627 & 627 & 646 & 646 & 627 & 627 \\
\hline$A d j . R^{2}$ & 0.97 & 0.95 & 0.92 & 0.92 & 0.97 & 0.96 & 0.93 & 0.93 \\
\hline$U$ & & & $\begin{array}{c}6.23 \\
{[0.044]}\end{array}$ & $\begin{array}{c}6.61 \\
{[0.037]}\end{array}$ & & & $\begin{array}{c}5.53 \\
{[0.063]}\end{array}$ & $\begin{array}{c}7.75 \\
{[0.021]}\end{array}$ \\
\hline$H$ & & & $\begin{array}{c}0.49 \\
{[0.486]}\end{array}$ & $\begin{array}{c}1.11 \\
{[0.291]}\end{array}$ & & & $\begin{array}{c}0.29 \\
{[0.588]}\end{array}$ & $\begin{array}{c}0.21 \\
{[0.643]}\end{array}$ \\
\hline$W$ & & & 28.32 & 14.80 & & & 15.31 & 7.39 \\
\hline
\end{tabular}

Notes: All variables are expressed in logs. P-values in brackets. OLS: Ordinary Least Squares.

FE: Fixed Effects. FE-2SLS: Fixed effects usizzos Two Step Least Squares.

$U$ : Under identification test. $H$ : Hansen test. $W$ : Weak identification test. 
In any case, whether the increase in the payroll taxes caused significant job cuts, or not, in Colombia is something we cannot answer properly in this study. It is generally expected that the larger the extent of payroll tax shifting on net wages, the lower the negative consequences on employment. However, there is not yet a consensus in the literature on the fact that cutting payroll taxes increases employment (and vice-versa). Rather, the empirical evidence suggests that payroll taxation might have asymmetric effects on wages and employment. On one side, there are studies suggesting that payroll tax increases have negative effects on net wages and employment -Kugler and Kugler (2009), Beach and Baulfour (1983), and Hamermesh (1979); while, on the other side, there are even more studies showing that payroll tax rate cuts do not generate significant effects on employment, even though they have sizeable positive effects on net real wages -Cruces et al. (2010), Bennmarker et al. (2009), Bauer and Riphahn (2002), and Gruber $(1997) \cdot{ }^{17}$

In the case of the unemployment rate, the results differ between models. Estimates for model (2) point to the irrelevance of unemployment on wage determination (see the non-significant coefficients in columns 3 and 4), while the estimates for model (3) suggest a significant and positive influence, at odds the standard theoretical prediction (columns 7 and 8 ). On this account, we have verified a negative correlation of 0.59 between the unemployment rate and the price wedge, which seems to be affecting the estimated coefficient on unemployment (the one on the price wedge is robust to the absence of unemployment as explanatory variable, but the contrary does not hold). This is the reason why we credit the results from model (2). In this way, the irrelevance of urban unemployment as determinant of net real wages may be a reflection that it is a poor proxy of the dynamics of industrial unemployment or, being a reasonable proxy after all, may be a proof of the findings in Iregui et al. (2012), who show that Colombian firms consider some aggregate factors, the unemployment rate among them, as having minor relevance in determining nominal wage increases.

The last result is the scant influence exerted by the degree of international trade openness on wage setting. The short-run elasticity, which is 0.08 and increases to 0.11 in the long-run, indicates that a $1 \%$ increase in the degree of trade openness causes net real wages to grow by $0.11 \%$. This result is not surprising given that in the seventies and eighties Colombia was a closed economy, and the industry was mainly based on manufactures that had a low international exposure. Of course, some branches had already high rates of trade openness (for example, the manufacture of machinery and equipment;

\footnotetext{
${ }^{17}$ There is also an issue related to the consequences of changes in social protection systems (and the corresponding taxation changes) on formal and informal employment. For Colombia this is studied in Camacho et al. (2014), who show that informal employment increased by 4 percentage points as a consequence of the government's expansion of social programs in the early 1990s.
} 
and medical instruments), but they represented a minimal share of the industry $(2.4 \%)$.

Table 5. Long-run elasticities.

\begin{tabular}{|c|c|c|c|c|c|c|c|c|}
\hline \multicolumn{9}{|c|}{ 1976-1991 } \\
\hline & \multicolumn{4}{|c|}{ MODEL I } & \multicolumn{4}{|c|}{ MODEL II } \\
\hline & OLS & $\mathrm{FE}$ & FE-2SLS & FE-2SLS & OLS & $\mathrm{FE}$ & FE-2SLS & FE-2SLS \\
\hline & (1) & $(2)$ & $(3)$ & $(4)$ & $(5)$ & $(6)$ & $(7)$ & $(8)$ \\
\hline$\xi_{(Y / N)}$ & 0.41 & 0.05 & 0.44 & 0.44 & 0.40 & 0.07 & 0.50 & 0.43 \\
\hline$\xi_{u}$ & -0.56 & -0.25 & -0.07 & -0.20 & -0.07 & 0.08 & 0.20 & 0.34 \\
\hline$\xi_{W^{\min }}$ & 1.83 & 1.18 & 1.05 & 1.30 & & & & \\
\hline$\xi_{\pi}$ & & & & & -7.48 & -3.19 & -4.34 & -5.80 \\
\hline$\xi \tau^{p}$ & -1.93 & -0.41 & -1.21 & -1.30 & -2.25 & -0.34 & -1.35 & -1.52 \\
\hline$\xi_{o p}$ & 0.07 & -0.01 & 0.11 & 0.11 & 0.06 & -0.01 & 0.11 & 0.10 \\
\hline \multicolumn{9}{|c|}{ 1992-2009 } \\
\hline & \multicolumn{4}{|c|}{ MODEL I } & \multicolumn{4}{|c|}{ MODEL II } \\
\hline & OLS & $\mathrm{FE}$ & FE-2SLS & FE-2SLS & OLS & $\mathrm{FE}$ & FE-2SLS & FE-2SLS \\
\hline & (1) & $(2)$ & (3) & (4) & (5) & (6) & (7) & (8) \\
\hline$\xi_{(Y / N)}$ & 0.40 & -0.01 & 0.29 & 0.29 & 0.41 & 0.02 & 0.40 & 0.28 \\
\hline$\xi_{u}$ & -0.89 & -0.07 & -0.24 & -0.35 & 0.80 & 0.04 & -0.44 & 0.06 \\
\hline$\xi_{W^{\min }}$ & 4.54 & 1.25 & 1.20 & 1.33 & & & & \\
\hline$\xi_{\pi}$ & & & & & -17.8 & -4.05 & -5.53 & -6.04 \\
\hline$\xi_{\tau^{p}}$ & -4.44 & -0.32 & -0.90 & -0.86 & -9.84 & -1.51 & -3.02 & -2.95 \\
\hline$\xi_{o p}$ & 0.00 & -0.05 & 0.15 & 0.15 & 0.00 & -0.05 & 0.17 & 0.12 \\
\hline
\end{tabular}

In any case, the positive influence of trade openness on wage setting should be interpreted in connection to the works by Amiti and Davis (2011) and Arbache et al. (2004). That is, our result is on one side connected to the positive relationship between wages and the import of intermediate goods, which was large in the Colombian industry. And, on the other side, to the hypothesis of skill-biased technological change and the subsequent increase in skilled-labor wages, which is likely to apply to those manufacturing sectors more (and growingly) exposed to international trade.

Finally, the macroeconomic shocks controlled by the additive dummies $\left(d^{8083}, d^{9700}\right.$, and $d^{0809}$ ) have had, in general, a significant influence on wages (although there are some exceptions depending on the specification): clearly negative during the debt and Great Recession crises, but not conclusive during the financial bubble and burst of the second half of the nineties. 


\subsection{Wage setting with enhanced labor flexibility, payroll taxa- tion, and trade exposure (1992-2009)}

The analysis of the interactions allows us to check for the existence of structural changes in the wage setting effects of the various determinants.

A first salient result (robust across estimation methodologies and model specification) is an increase in wage persistence ranging from 0.32-0.35 in model (3), to 0.46-0.48 in model (2). This increase runs in parallel to the lower volatility of real net wages in the Colombian industry in 1992-2009 (specifically in 1995-2005), which echoes a much reduced volatility in the rate of inflation. In addition, the larger persistence is accompanied by lower short-run coefficients, so that it is the relative magnitude of these changes what determines the variation in the long-run response of wages to its various determinants. ${ }^{18}$

Regarding the relationship between wages and labor productivity, we find a fall in the long-run elasticity, going from 0.44 to 0.29 in model (2), and from 0.43 to 0.28 in model (3) (see Table 6, columns 4 and 8). This implies that the relationship between these two variables has become weaker. This can be considered one of the collateral pitfalls of the institutional and trade reform process since it is tempting to associate this finding to the increasing current account deficit experienced by Colombia in the last decades. The counterpart is, of course, that wage setting has become more persistent.

In contrast with productivity, the long-run elasticity of wages with respect to minimum wages remained unaltered around 1.3 in 1992-2009. This implies that the institutional and trade reforms have not crucially affected the adjustments of net real wages vis-à-vis the net real minimum wage. This stability is confirmed when looking at the role played by the price wedge in model (3) which remains quite stable (with a slight increase in the long-run elasticity going from -5.80 to -6.04 in 1992-2009. In any case, this mildly larger sensitivity can be associated to the fact that adjustments in nominal wages became more tied to CPI inflation since 1991, and also to the increased exposure to international markets and the resulting dramatic downward pressures on producer and consumer prices. As noted before, the asymmetric price response to these pressures caused a fall in the price wedge. Thus, in the growingly liberalized environment of 1992-2009, this increased sensitivity to the price wedge should come as no surprise.

Together with the result on productivity, another key novelty in this period is that net real wages became less sensitive to changes in payroll taxes with a long-run elasticity falling from -1.30 to -0.86 in model (2). Although, the long-run coefficients of payroll taxes in model (3) increase when interacted with $d^{92}$, it is important to note their lack of

\footnotetext{
${ }^{18}$ Note that, as wage persistence increases, the long-run coefficients have a tendency to become larger. However, this increase might be offset, or even overtaken, by the falls in the short-run wage elasticities.
} 
significance (column 8 in Table 4). According to this result, and taking into account the weaker instruments of this specification, we credit the findings obtained through model (2).

This lower sensitivity of wages with respect to payroll taxes takes place in the context of their significant rise in the 1990s. This result is consistent with the previous ones along the following lines. Recall that firms can shift the tax burden on workers through lower nominal net wages or higher prices. In a growing liberalized labor market, wage cuts become more feasible than rising prices (in an otherwise growing open environment), hence the preferred use of the first channel. However, the new situation of full indexation of nominal wages to the cost of living in the nineties was effectively introducing wage floors to firms. These wage rigidities, which prevented firms to shift the tax burden to the workers in the form of lower net wages, help to explain why the sensitivity of wages with respect to payroll taxes becomes lower in this period.

The last finding is related to the increase in the long-run elasticity of wages with respect to the degree of trade openness, which rises from 0.11 to 0.15 in model (2), and from 0.10 to 0.12 in model (3). This increase is consistent with the predicted behavior of wages according to the work by Arbache et al. (2004). Following a wide liberalization process, the relative demand for skilled labor in developing countries is expected to rise, thus leading to wage increases in this group of workers.

\section{Multiplicative interactions and marginal effects}

As a complementary exercise, in this Section we present the crucial findings from the estimation of equations (2) and (3) as multiplicative interaction models (see Berry et al., 2012 , for details). Although this procedure is not suitable to investigate changes in the form of structural breaks, it gives us further insights on the relationship between wages and their main determinants when they are assumed to be cross-dependant.

In particular, we look at the marginal effects of real minimum wages and the price wedge on net real wages, conditional on the different values taken by payroll taxation and the degree of trade openness in 1976-1991 and 1992-2009. In this way, we check whether the reform process (increases in the exposure to international trade and payroll taxation) have affected the way wages react to these key determinants.

Thus, the new models considered take the following general form:

$$
W_{i t}=\alpha_{i}+\gamma W_{i t-1}+\beta_{X} X_{i t}+\beta_{X \tau}\left(X_{i t} * \tau_{t}^{p}\right)+\beta_{o p}\left(X_{i t} * o p_{i t}\right)+\beta_{\tau o p}\left(X_{i t} * \tau_{t}^{p} * o p_{i t}\right)+\lambda \mathbf{Z}_{i t}+e_{i t}
$$

where $X$ is a scalar comprising our two variables of interest, $W_{t}^{\min }$ and $\pi_{t}$; and $\mathbf{Z}_{i t}$ is a 
vector comprising the rest of the explanatory variables $-Y_{i t} / N_{i t}, u_{t}, \tau_{t}^{p}$ and $o p_{i t}-$ and various controls. $^{19}$

The marginal effects of our variables of interest will thus be given by: ${ }^{20}$

$$
\frac{\partial w_{i t}}{\partial X_{i t}}=\alpha_{i}+\beta_{X}+\beta_{X \tau} \tau_{t}^{p}+\beta_{o p} o p_{i t}+\beta_{\tau o p}\left(\tau_{t}^{p} * o p_{i t}\right)
$$

These marginal effects are presented in figures 4 and 5. Different values of trade openness (in logs) are listed in the horizontal axis, while the left vertical axis shows the histogram of trade openness corresponding to its distribution in 1976-1991 (in panel a) and 1992-2009 (in panel b). In the turn, the values in the right vertical axis indicate the magnitude of the marginal effect. The marginal effects are evaluated at the average payroll tax rate in each period. Note, also, that Figure 4 corresponds to the model specification with real minimum wages (column 4 in Table A2), while Figure 5 corresponds to the model specification with the price wegde (column 8 in Table A2).

Figure 4. Marginal effects of real minimum wages on net real wages.
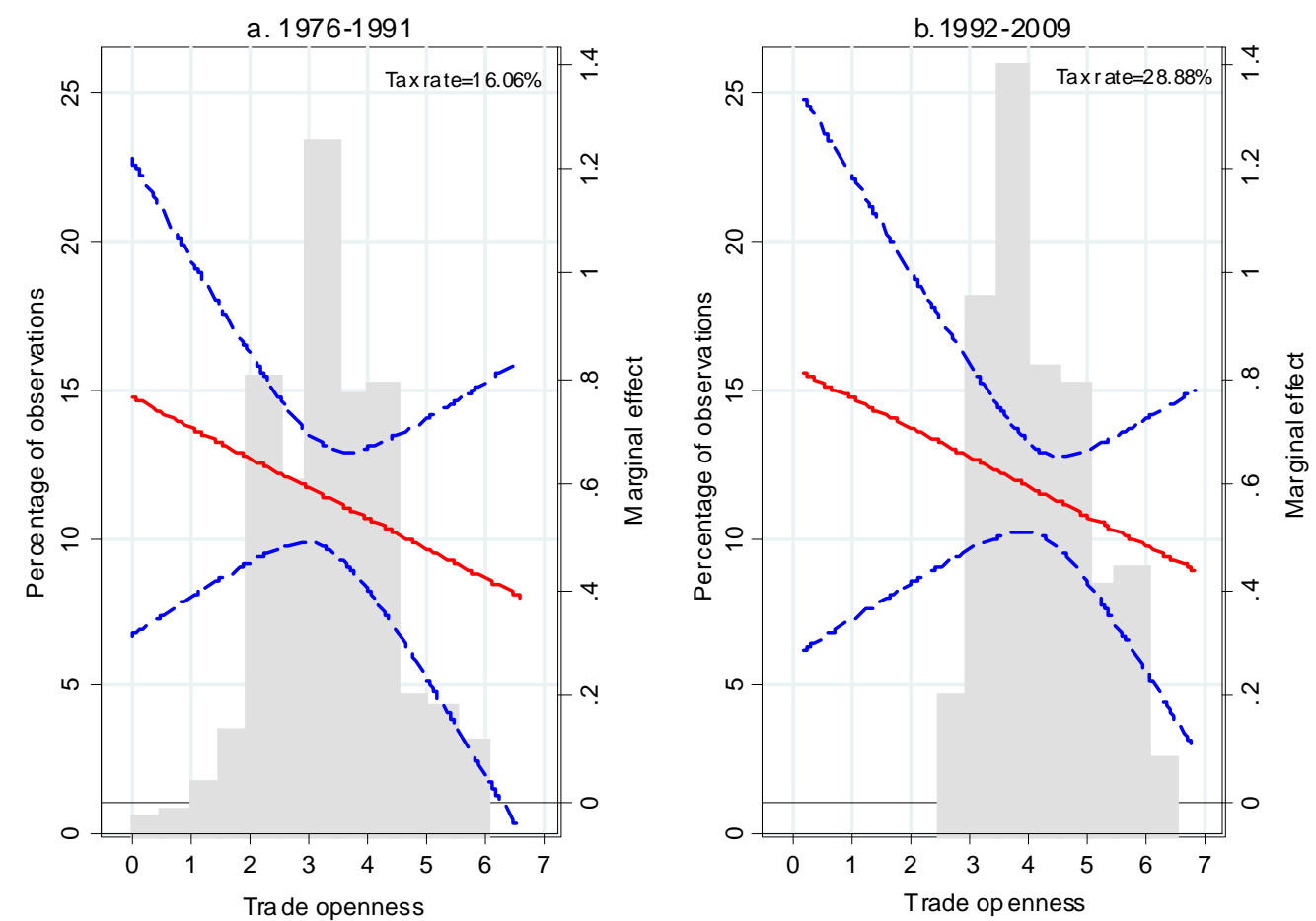

Notes: Dash lines represent 95\% confidence interval. Trade openness in log.

\footnotetext{
${ }^{19} \mathrm{We}$ also conducted the analysis having labor productivity interacted with payroll taxes and the degree of trade openness, but it was not successful. Still, the results are available upon request.

${ }^{20}$ The corresponding estimated equations are presented Table A3 in the Appendix. Here we only focus on the marginal effects derived from those estimations (more precisely, those presented in columns 4 and 8 in consistence with Section 5).
} 
The marginal effects of real minimum wages range between 0.4 and 0.8 depending on the degree of trade openness. Looking at the histogram, this range can be further narrowed to the interval 0.5-0.7 for the relevant values of trade openness in 1976-1991 (those between $7 \%$ and $55 \%$ corresponding to 2 and 4 in logs, as shown in Figure 4a) and to 0.55-0.65 in 1992-2009 (Figure 4b). Colombia was a relatively more open economy in 1992-2009, this is why the histogram shifts to the right. However, when the marginal effects are evaluated at the relevant trade openness and payroll tax values, there is no difference on the extent of the wage impact of real minimum wages. This result is consistent with the lack of structural change in this elasticity when evaluated through the analysis of multiplicative dummies as in Section 5 .

Of course, this conclusion does not preclude the fact that larger values of trade exposure tend to reduce the sensitivity of wages with respect to the minimum wage. The point here is that this changing sensitivity has not shifted, on aggregate, in the new scenario of labor market flexibility and enhanced trade liberalization. The implicit result at the sectoral level is that more open sectors will tend to have less responsive wages to changes in the minimum wage.

Figure 5 shows the marginal effects of the price wedge.

Figure 5. Marginal effects of the price wedge on net real wages.
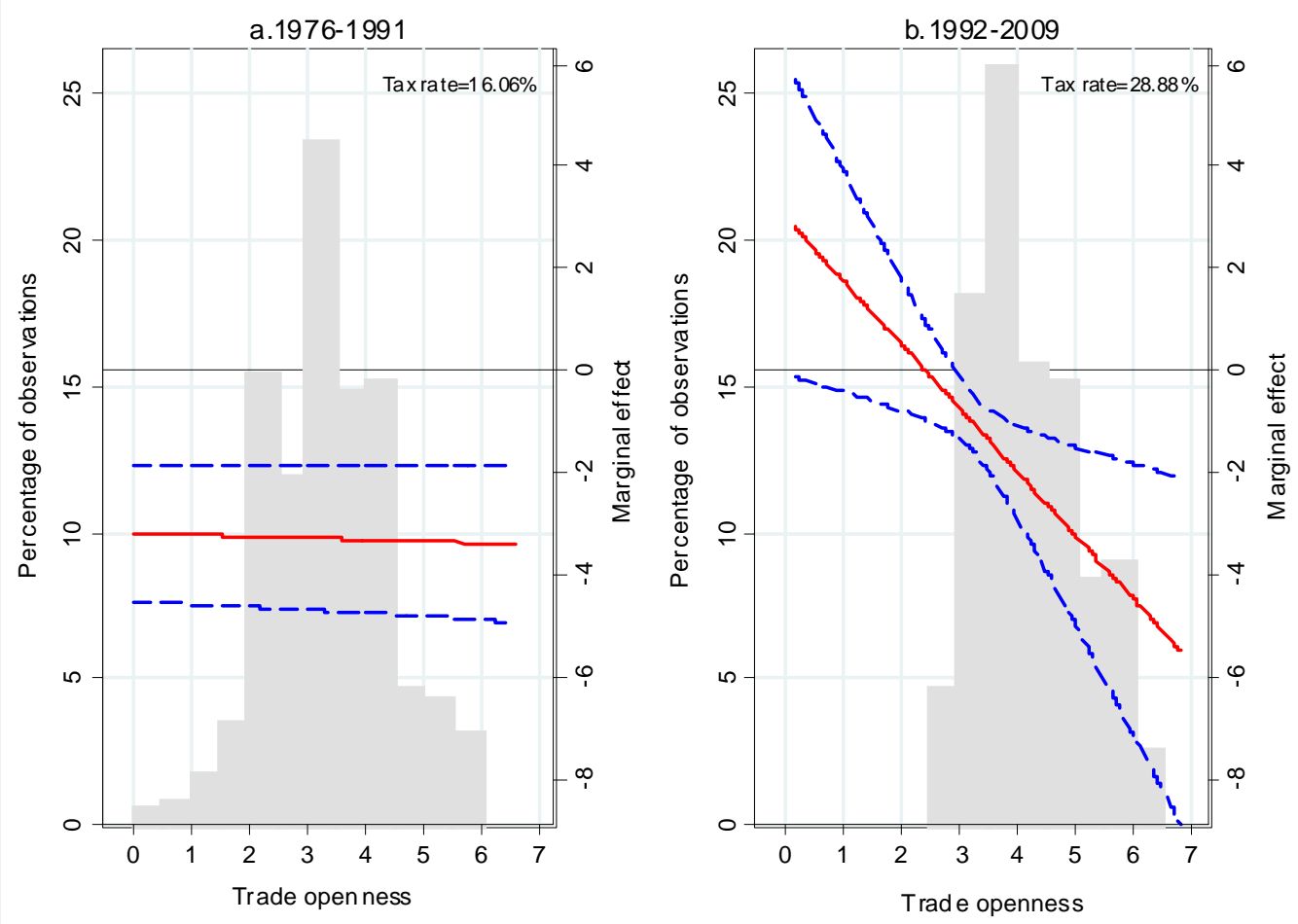

Notes: Dash lines represent 95\% confidence interval. Trade openness in log.

The first remark on these results is that the marginal effects are negative and consistent 
with the analysis in Section 5. The second remark points to the flat slope in the first period, when payroll taxation was low on average (Figure 5a), which indicates that the sensitivity of wages with respect to the price wedge is not affected by the degree of trade openness.

In contrast, in a scenario of high payroll taxation such as the one in 1992-2009, the marginal effects are negatively sloped (Figure 5b). This implies that the sensitivity of real wages to the price wedge gets larger along with the degree of trade openness (cases of extreme openness, such as the ones in the right hand side of the histogram, correspond to the few very much open manufacturing sectors reported in the Appendix). This larger sensitivity goes in line with Bems (2014), who points out that increasing input imports leads to a greater response of the relative price to a given external adjustment.

\section{Concluding remarks}

We have studied wage determination in the Colombian manufacturing industry and paid specific attention to the consequences of the institutional and trade reforms carried out in Colombia during the nineties.

The first salient result is that productivity is not fundamentally driven by labor productivity in contrast to the standard theoretical prediction. In addition, the long-run elasticity of wages with respect to productivity has decreased to 0.30 in the nineties and noughties, from a value close to 0.45 .

This suggests that the institutional measures undertaken by the government did not improve the scarce connection between workers' compensation and labor's efficiency progress. On the contrary, this connection has been worsened. Taking the benchmark oneto-one relationship between wages and productivity, the failure to reduce this detachment (or, even worse, increasing it) in a growing globalized economy should be given priority from policy makers, as it generates distortions in the process of achieving competitiveness in the manufacturing sector. This is the main lesson that can be drawn from our study in terms of policy measures.

If the Colombian economy continues to globalize at the same pace than in the last two decades, this call to strengthen the link between wages and productivity should be further reinforced.

Another main result is that wage progress in Colombia is largely tied to the cost of living. This conclusion is obtained from the important role played by the real minimum wage, or alternatively by the price wedge between manufacturing and consumer prices, as wage drivers. Here, however, we find no evidence of structural changes in the corresponding long-run relationships. It seems, therefore, that the purchasing power of workers has 
remained relatively isolated from the new institutional and trade scenario.

In terms of payroll taxation (paid by firms), we find the expected negative impact on net real wages, although we are unable to evaluate the net employment consequences of the increase in payroll taxes in the nineties. Our contribution here is the identification of a fall in the wage elasticity with respect to these taxes (from 1.3 to 0.86 ), which is the joint outcome of changes in the institutional setting such as the enhanced indexation of nominal wages to CPI inflation, and the asymmetric downward pressures on manufacturing and consumption prices resulting from the liberalization process. The consequence of this lower tax shifting is a loss in firms' cost competitiveness which, although we have not dealt with it, may use employment as an instrument to offset this loss.

What is, then, the counterpart of the lower explanatory power of productivity?

On one side, wage persistence has increased. This is connected to the lower capacity of firms to shift taxes. Although firms can shift the tax burden on workers through lower nominal net wages or higher prices, in a growingly liberalized labor market wage cuts become more feasible than rising prices. Hence the preferred use of wage cuts. However, the new situation of full indexation of nominal wages to the cost of living in Colombia in the nineties was effectively introducing wage floors to firms. This explains the increase in wage persistence.

On the other side, the long-run elasticity of wages with respect to the degree of trade openness did also increase. This suggests that, following the liberalization process, the relative demand for skilled labor went up and pushed the compensation of this type of workers.

As a complementary exercise, we have also examined the marginal effects of real minimum wages and the price wedge on net real wages, conditional on the different values taken by payroll taxation and the degree of trade openness in 1976-1991 and 1992-2009. In this way, we have checked, from a different perspective, whether the impact of these wage determinants has changed along with the reform process. We have confirmed the stability of the relationship between net wages and the minimum wage, but we have identified a different sensitivity with respect to the price wedge depending on the level (low or high) of payroll taxation. This requires further research.

Overall, our findings call for a policy agenda in which wage indexation is reduced and a true wage bargaining system is brought in. This would allow workers' compensation to reflect more faithfully efficiency progress which, by all means, should be a critical target to solve the competitive problem of the Colombian industry and help, in this way, rebalancing the huge trade deficit attained with the liberalization program.

Our analysis can be refined in a variety of directions. Further research should control for types of employment given that, both institutional and trade reforms, may have differ- 
ent effects on wages by type of worker. For example, regarding payroll taxes, international evidence suggests that there is less tax shifting for blue-collar than for white-collar workers. Beyond that, for developing countries there is growing empirical evidence showing that trade liberalization exerts a positive effect on high-skill labor wages, while there is no effect on low-skill labor wages.

Another research avenue is to aim at an individual assessment of how these reforms affected wage setting in each productive sector. In that case, the starting hypothesis would be that each sector's response is connected to its degree of exposure to international trade.

\section{References}

[1] Anderson, T.W and C. Hsiao (1982): "Formulation and estimation of dynamic models using panel data", Journal of Econometrics, 18, pp. 47-82.

[2] Amiti, M. and D.R. Davis (2011): "Trade, Firms and Wages: Theory and Evidence, Review of Economic Studies, 79, pp. 1-36.

[3] Arbache, J., A. Dickerson, and F. Green (2004): "Trade Reforms and Wages in developing countries", Review of Economics Studies, 58, pp. 277-297.

[4] Arellano, M., and S. Bond (1991): "Some Test of Specification for Panel Data: Montecarlo Evidence and an Application to Employment Equations", Review of Economics Studies, 58, pp. 277-297.

[5] Arellano, M., and O. Bover (1995): "Another Look at the instrumental Variables Estimation of Error-components Models", Journal of Econometrics, 68, pp. 29-51.

[6] Attanasio, O., P. Goldeberg, and N. Pavcnik (2004): "Trade Reforms and Wage Inequality in Colombia", Journal of Development Economics, 74, pp. 331-366.

[7] Autor, D.H., D. Dorn, G.H. Hanson, and J. Song (2014): "Trade Adjustment: Worker Level Evidence", Quarterly Journal of Economics, 129(4), pp. 1799-1860.

[8] Autor, D.H., D. Dorn, and G.H. Hanson (2014): "The China Syndrome: Local Labor Market Effects of Import Competition in the United States", The American Economic Review, 103(6), pp. 2121-2168.

[9] Bauer, T. and R. Riphahn (2002): "Employment Effects of Payroll Taxes, an Empirical Test for Germany", Applied Economics, 34, pp. 865-76.

[10] Beach, C.M. and F.S. Baulfour (1983): "Estimated Payroll Tax Incidence and Aggregate Demand for labour in the United Kingdom", Economica, 50(197), pp. 35-48.

[11] Bems, R. (2014): "Intermediate inputs, external rebalancing and relative price adjustment", Journal of International Economics, 94 (2), pp. 248-262.

[12] Bennmarker, B., E. Mellander, and B. Ocker (2009): "Do regional payroll tax reductions boost employment?", Journal of Labor Economics, 16(1), pp. 480-89.

[13] Bruno, G.S. F. (2005): "Approximating the bias of the LSDV estimator for dynamic unbalanced panel data models", Economics Letters, 87(3), pp. 361-366.

[14] Berry, W.D., M. Golder, and D. Milton (2012): "Improving Test of Theories Posting Interaction", The Journal of Politics, 74(3), pp. 653-671. 
[15] Booth, A. (2014): "Wage Determination and Imperfect Competition", IZA Discussion Paper No. 8034, IZA, Bonn, Germany.

[16] Blundell, R. and S. Bond (1998): "Initial conditions and moment restrictions in dynamic panel data models", Journal of Econometrics, 87, pp. 115-143.

[17] Camacho, A., E. Conover, and A. Hoyos (2014): "Effects of Colombia's Social Protection System on Workers' Choice between Formal and Informal Employment", The World Bank Economic Review, vol. 28 (3), pp. 446-466.

[18] Caselli, M. (2014): "Trade, skill-biased technical change and wages in Mexican manufacturing ", Applied Economics, vol. 46 (3), pp. 336-348.

[19] Cragg, M. and M. Epelbaum (1996): "Initial conditions and moment restrictions in dynamic panel data models", Journal of Econometrics, 87, pp. 115-143.

[20] Cruces, G., S. Galiani and S. Kidyba (2010): "Payroll taxes, wages and employment: Identification through policy changes", Labour Economics, 17, pp. 743-49.

[21] Dreher, A., N. Gaston, and P. Martens (2008): Measuring Globalisation - Gauging its Consequences, New York: Springer.

[22] Fisher, R. A. (1932): Statistical Methods for Research Workers, 4th Edition, Edinburgh: Oliver \& Boyd.

[23] Gruber, J. (1997): "The Incidence of Payroll Taxation: Evidence from Chile", Journal of Labor Economics, 15(3), pp. S72-S101.

[24] Hamermesh, D. (1979): "New Estimates of the Incidence of the Payroll Tax", Southern Economic Journal, 45, pp.1208-1219.

[25] Hofstetter, M. (2005): "Política monetaria y la corte constitucional: El caso del salario mínimo", Documento CEDE 2005-36, ISBN/ISSN: 1657-5334.

[26] Im, K.S, M.H. Pesaran, and Y. Shin (2003): "Testing for unit roots in heterogeneous panels", Journal of Econometrics, 115, pp. 53-74.

[27] Judzik, D. and H. Sala (2013): "Productivity, deunionization and trade: wage effects and labour share implications", International Labour Review, 152 (2), pp. 205-236.

[28] Judson, R. A., and A.L. Owen (1999): "Estimating dynamic panel data models: A guide for macroeconomists", Economic Letters, 65, pp.9-15

[29] Kwiatkowski, D., P. Phillips, P. Smith, and Y. Shin (1992): "Testing the null hypothesis of stationary against the alternative of unit root: how sure are we that economic time series are not stationary?", Journal of Econometrics, 54, pp.159-178.

[30] Kugler, A. and M. Kugler (2009): "The labor market effects of payroll taxes in a middleincome country: evidence from Colombia," Economic Development and Cultural Change, 57 (2), pp. 335-358.

[31] Iregui, A., L. Melo and M. Ramírez (2012): "Wage Adjustment Practices and the Link between Price and Wages: Survey Evidence from Colombian Firms", Lecturas de Economía, 76, pp.17-53.

[32] Levin, A. and C. Lin (1993): "Unit Root Tests in panel data: New Results", Discussion paper No. 93-56, Department of Economics, University California at San Diego.

[33] Lindbeck, A., and D.J. Snower (2001): "Insiders versus Outsiders", Journal of Economic Perspectives, 15 (1), pp. 165-188. 
[34] Maddala, G.S and S. Wu (1999): "A Comparative study of unit root tests with panel data and new simple test", Oxford Bulletin of Economics and Statistics, 61, pp. 631-652.

[35] Meschi, E., and M.Vivarelli (2009): "Trade and Income Inequality in Developing Countries" World Development, 37 (2), pp. 287-302.

[36] Nickell, S. (1981): "Biases in dynamic models with fixed effects", Econometrica, 49(6), pp. 1417-26.

[37] Podrecca, E. (2011): "Labour market institutions and wage setting: evidence for OECD countries ", Applied Economics, 43, pp. 3671-3686.

[38] Staiger, D. and J.H. Stock (1997): "Instrumental variables regression with weak instruments", Econometrica, 65, pp. 557-586.

[39] Stock, J.H., Yogo, M. (2005): "Testing for weak instruments in linear IV regression". In: Stock, J.H., Andrews, D.W.K., (Eds.), Identification and Inference for Econometric Models: A Festschrift in Honor of Thomas Rothenberg. Cambridge University Press, Cambridge, pp. 80-108. (Ch. 5)

[40] Summers, L.H. (1989): "Some Simple Economics of Mandated Benefits", The American Economic Review, Papers and Proceedings, 79 (2), pp. 177-83.

\section{Appendix}

\section{Figure A1. Export and import shares, and trade deficit of the manufacturing industry. 1975-2010.}

a. Export and import shares

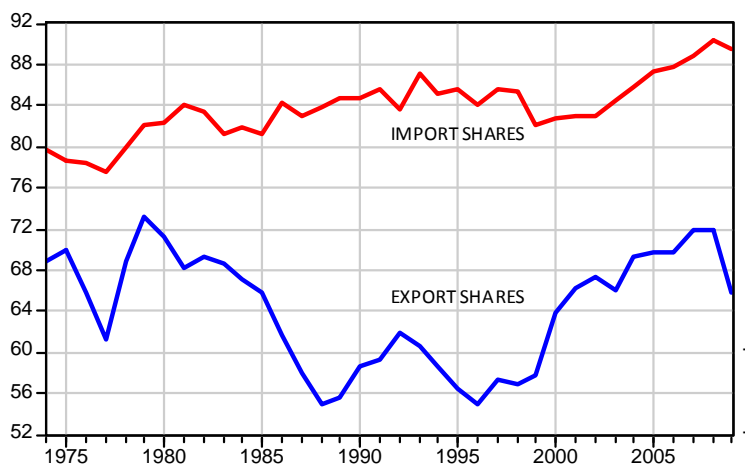

b. Trade deficit (\% GDP)

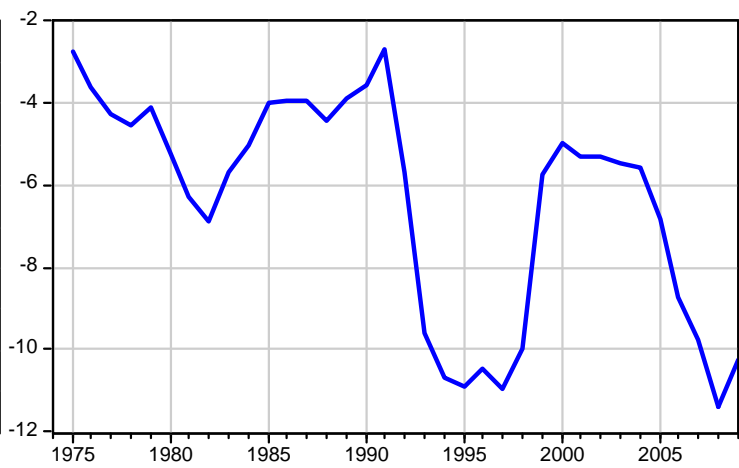

Source: DANE.

Table 1 informs on the homogeneity of the opening process across sectors. Within this relatively homogeneous process, we acknowledge that some branches experienced particularly intensive opening processes. Two of them were already globalized in 1974-1991 (S15 on manufacture of machinery and equipment including manufacture of office, accounting and computing machinery, 232\%; and S17 on manufacture of medical, precision and optical instruments, watches and clocks, 156\%), but reached degrees of trade openness of $387 \%$ and $226 \%$, respectively, in 1992-2009. The three other ones departed from values much below, but also became fully opened industries in 1992-2009: S16 on manufacture of 
electrical machinery, radio, television and communication equipment, 256\%; S18 on manufacture of motor vehicles, trailers and semi-trailers, and other transport equipment, 151\%; and S19 on manufacture of furniture, 125\%. This particularly intensive transformations are taken into account in our empirical analysis.

Table A1. Trade openness and output shares by industries.

\begin{tabular}{|c|c|c|c|c|}
\hline \multirow[t]{2}{*}{ Sector } & \multicolumn{2}{|c|}{ Trade openness } & \multicolumn{2}{|c|}{ Share in total industry GDP } \\
\hline & 1974-1991 & $1992-2009$ & 1974-1991 & $1992-2009$ \\
\hline $\mathrm{S} 2$ & 5.1 & 29.2 & 2.6 & 0.7 \\
\hline S11 & 8.3 & 42.3 & 4.2 & 5.0 \\
\hline S1 & 9.7 & 28.2 & 28.4 & 28.9 \\
\hline S3 & 11.6 & 68.8 & 10.9 & 5.3 \\
\hline $\mathrm{S} 12$ & 13.3 & 22.1 & 5.8 & 7.3 \\
\hline S6 & 19.2 & 36.8 & 0.8 & 0.6 \\
\hline S7 & 23.1 & 39.5 & 3.7 & 3.8 \\
\hline S5 & 23.4 & 69.6 & 1.7 & 1.1 \\
\hline S14 & 24.5 & 60.3 & 3.7 & 2.8 \\
\hline S8 & 25.7 & 23.7 & 2.8 & 3.6 \\
\hline $\mathrm{S} 4$ & 29.2 & 39.2 & 3.0 & 3.6 \\
\hline S19 & 39.9 & 125 & 1.6 & 1.2 \\
\hline S10 & 47.6 & 79.8 & 12.8 & 15.4 \\
\hline S9 & 52.2 & 44.5 & 4.3 & 9.0 \\
\hline S18 & 59.7 & 151 & 4.1 & 3.2 \\
\hline S16 & 64.2 & 256 & 3.2 & 2.2 \\
\hline S13 & 71.9 & 111 & 4.0 & 3.9 \\
\hline S17 & 156 & 226 & 0.5 & 0.7 \\
\hline S15 & 232 & 387 & 1.9 & 1.7 \\
\hline Total & 48.2 & 96.8 & 100 & 100 \\
\hline
\end{tabular}

Notes: Classification based on International Standard Industrial Classification, Rev. 3.

All variables are expressed in percent. Sectors: Manufacture of food products and beverages (S1); Manufacture of tobacco products (S2); Manufacture of textiles (S3); Manufacture of wearing apparel; dressing and dyeing of fur (S4); Tanning and dressing of leather; manufacture of luggage, handbags, saddlery, harness and footwear (S5); Manufacture of wood and of products of wood and cork, except furniture; manufacture of articles of straw and plaiting materials (S6); Manufacture of paper and paper products (S7); Publishing, printing and reproduction of recorded media (S8); Manufacture of coke, refined petroleum products and nuclear fuel (S9); Manufacture of chemicals and chemical products (S10); Manufacture of rubber and plastics products (S11); Manufacture of other non-metallic mineral products (S12); Manufacture of basic metals (S13); Manufacture of fabricated metal products, except machinery and equipment (S14); Manufacture of machinery and equipment n.e.c.; and manufacture of office, accounting and computing machinery (S15); Manufacture of electrical machinery and apparatus n.e.c.; and manufacture of radio, television and communication equipment and apparatus (S16); Manufacture of medical, precision and optical instruments, watches and clocks (S17); Manufacture of motor vehicles, trailers and semi-trailers, and other transport equipment (S18); Manufacture of furniture; manufacturing n.e.c. (S19). 
Table A2. Bias-corrected LSDVC estimators.

\begin{tabular}{lcccccccc}
\hline \hline & \multicolumn{3}{c}{ MODEL I } & & \multicolumn{3}{c}{ MODEL II } \\
\cline { 2 - 4 } \cline { 7 - 8 } Bias order & AH & AB & BB & & AH & AB & BB \\
\cline { 2 - 3 }$(1 / T)$ & 0.42 & 0.45 & 0.46 & & 0.57 & 0.57 & 0.60 \\
$\mathrm{O}(1 / N T)$ & 0.42 & 0.46 & 0.47 & & 0.58 & 0.59 & 0.61 \\
$\mathrm{O}\left(1 / N^{-1} T^{-2}\right)$ & 0.42 & 0.47 & 0.52 & & 0.58 & 0.60 & 0.69 \\
\hline \hline
\end{tabular}

Notes: This table only displays persistence coefficients. Columns provide the consistent estimator chosen to initialize the bias correction. $\mathrm{AH}=$ Anderson and Hsiao (1982);

$\mathrm{AB}=$ Arellano and Bond (1991); $\mathrm{BB}=$ Blundell and Bond (1998). 
Table A3. Multiplicative interaction models.

\begin{tabular}{|c|c|c|c|c|c|c|c|c|}
\hline \multicolumn{9}{|c|}{ Dependent variable: $W_{i t}$} \\
\hline & \multicolumn{4}{|c|}{ MODEL I } & \multicolumn{4}{|c|}{ MODEL II } \\
\hline & OLS & FE & FE-2SLS & FE-2SLS & OLS & $\mathrm{FE}$ & FE-2SLS & FE-2SLS \\
\hline & $(1)$ & $(2)$ & $(3)$ & $(4)$ & $(5)$ & $(6)$ & $(7)$ & $(8)$ \\
\hline$W_{i t-1}$ & $\begin{array}{c}0.88 \\
{[0.000]}\end{array}$ & $\begin{array}{c}0.53 \\
{[0.000]}\end{array}$ & $\begin{array}{c}0.54 \\
{[0.000]}\end{array}$ & $\begin{array}{c}0.54 \\
{[0.000]}\end{array}$ & $\begin{array}{c}0.87 \\
{[0.000]}\end{array}$ & $\begin{array}{c}0.59 \\
{[0.000]}\end{array}$ & $\begin{array}{c}0.61 \\
{[0.000]}\end{array}$ & $\begin{array}{c}0.58 \\
{[0.000]}\end{array}$ \\
\hline$Y_{i t} / N_{i t}$ & $\begin{array}{l}0.05 \\
{[0.000]}\end{array}$ & $\begin{array}{l}0.02 \\
{[0.456]}\end{array}$ & $\begin{array}{c}-0.01 \\
{[0.312]}\end{array}$ & $\begin{array}{c}-0.01 \\
{[0.350]}\end{array}$ & $\begin{array}{l}0.05 \\
{[0.000]}\end{array}$ & $\begin{array}{c}0.03 \\
{[0.310]}\end{array}$ & {$\left[\begin{array}{c}0.01 \\
{[0.647]}\end{array}\right.$} & $\begin{array}{c}0.00 \\
{[0.904]}\end{array}$ \\
\hline$u_{t}$ & $\begin{array}{c}-0.12 \\
{[0.000]}\end{array}$ & $\begin{array}{c}-0.10 \\
{[0.000]}\end{array}$ & $\begin{array}{l}-0.10 \\
{[0.000]}\end{array}$ & $\begin{array}{c}-0.11 \\
{[0.000]}\end{array}$ & $\begin{array}{l}0.00 \\
{[0.753]}\end{array}$ & $\begin{array}{c}0.05 \\
{[0.007]}\end{array}$ & $\begin{array}{c}0.11 \\
{[0.000]}\end{array}$ & $\begin{array}{c}0.21 \\
{[0.000]}\end{array}$ \\
\hline$W_{t}^{\min }$ & $\begin{array}{l}0.21 \\
{[0.447]}\end{array}$ & $\begin{array}{l}0.50 \\
{[0.017]}\end{array}$ & $\begin{array}{l}0.50 \\
{[0.002]}\end{array}$ & $\begin{array}{l}0.50 \\
{[0.001]}\end{array}$ & & & & \\
\hline$\pi_{t}$ & & & & & $\begin{array}{l}-2.69 \\
{[0.019]}\end{array}$ & $\begin{array}{l}-3.09 \\
{[0.004]}\end{array}$ & $\begin{array}{c}-18.96 \\
{[0.000]}\end{array}$ & $\begin{array}{c}-32.79 \\
{[0.002]}\end{array}$ \\
\hline$\tau_{t}^{p}$ & $\begin{array}{l}-0.50 \\
{[0.492]}\end{array}$ & $\begin{array}{l}-0.60 \\
{[0.504]}\end{array}$ & $\begin{array}{l}-0.65 \\
{[0.484]}\end{array}$ & $\begin{array}{l}-0.68 \\
{[0.457]}\end{array}$ & $\begin{array}{c}-0.67 \\
{[0.000]}\end{array}$ & $\begin{array}{c}-0.50 \\
{[0.000]}\end{array}$ & $\begin{array}{c}-1.04 \\
{[0.000]}\end{array}$ & $\begin{array}{l}-1.55 \\
{[0.001]}\end{array}$ \\
\hline$o p_{i t}$ & $\begin{array}{c}0.06 \\
{[0.857]}\end{array}$ & $\begin{array}{c}0.39 \\
{[0.231]}\end{array}$ & $\begin{array}{l}0.40 \\
{[0.441]}\end{array}$ & $\begin{array}{l}0.41 \\
{[0.425]}\end{array}$ & $\begin{array}{c}0.00 \\
{[0.530]}\end{array}$ & $\begin{array}{c}-0.02 \\
{[0.165]}\end{array}$ & $\begin{array}{c}-0.01 \\
{[0.542]}\end{array}$ & $\begin{array}{l}0.00 \\
{[0.944]}\end{array}$ \\
\hline$W_{t}^{\min } * \tau_{t}^{p}$ & $\begin{array}{c}0.05 \\
{[0.573]}\end{array}$ & $\begin{array}{l}0.08 \\
{[0.439]}\end{array}$ & $\begin{array}{c}0.09 \\
{[0.374]}\end{array}$ & $\begin{array}{c}0.09 \\
{[0.352]}\end{array}$ & & & & \\
\hline$W_{t}^{\min } * o p_{i t}$ & $\begin{array}{c}-0.01 \\
{[0.916]}\end{array}$ & $\begin{array}{c}-0.06 \\
{[0.257]}\end{array}$ & $\begin{array}{c}-0.06 \\
{[0.470]}\end{array}$ & $\begin{array}{c}-0.06 \\
{[0.450]}\end{array}$ & & & & \\
\hline$W_{t}^{\min } * \tau_{t}^{p} * o p_{i t}$ & $\begin{array}{c}-0.00 \\
{[0.933]}\end{array}$ & $\begin{array}{l}0.00 \\
{[0.551]}\end{array}$ & $\begin{array}{l}0.00 \\
{[0.721]}\end{array}$ & $\begin{array}{l}0.00 \\
{[0.687]}\end{array}$ & & & & \\
\hline$\pi_{t} * \tau_{t}^{p}$ & & & & & $\begin{array}{c}0.47 \\
{[0.246]}\end{array}$ & $\begin{array}{c}0.53 \\
{[0.177]}\end{array}$ & $\begin{array}{c}5.96 \\
{[0.000]}\end{array}$ & $\begin{array}{l}10.68 \\
{[0.003]}\end{array}$ \\
\hline$\pi_{t} * o p_{i t}$ & & & & & $\begin{array}{l}0.01 \\
{[0.969]}\end{array}$ & $\begin{array}{c}0.02 \\
{[0.888]}\end{array}$ & $\begin{array}{c}3.13 \\
{[0.001]}\end{array}$ & $\begin{array}{l}5.80 \\
{[0.007]}\end{array}$ \\
\hline$\pi_{t} * \tau_{t}^{p} * o p_{i t}$ & & & & & $\begin{array}{c}-0.00 \\
{[0.650]}\end{array}$ & $\begin{array}{l}0.00 \\
{[0.970]}\end{array}$ & $\begin{array}{c}-1.13 \\
{[0.002]}\end{array}$ & $\begin{array}{c}-2.10 \\
{[0.002]}\end{array}$ \\
\hline$d_{8083}$ & $\begin{array}{l}-0.02 \\
{[0.137]}\end{array}$ & $\begin{array}{l}-0.04 \\
{[0.000]}\end{array}$ & $\begin{array}{l}-0.04 \\
{[0.000]}\end{array}$ & $\begin{array}{l}-0.04 \\
{[0.000]}\end{array}$ & $\begin{array}{c}-0.02 \\
{[0.071]}\end{array}$ & $\begin{array}{c}-0.02 \\
{[0.007]}\end{array}$ & $\begin{array}{c}-0.00 \\
{[0.780]}\end{array}$ & $\begin{array}{l}0.01 \\
{[0.515]}\end{array}$ \\
\hline$d_{9700}$ & $\begin{array}{c}0.03 \\
{[0.002]}\end{array}$ & $\begin{array}{c}0.03 \\
{[0.000]}\end{array}$ & $\begin{array}{l}0.02 \\
{[0.000]}\end{array}$ & $\begin{array}{c}0.02 \\
{[0.000]}\end{array}$ & $\begin{array}{l}-0.02 \\
{[0.001]}\end{array}$ & $\begin{array}{l}-0.04 \\
{[0.000]}\end{array}$ & $\begin{array}{l}-0.05 \\
{[0.000]}\end{array}$ & $\begin{array}{l}-0.07 \\
{[0.000]}\end{array}$ \\
\hline$d_{0809}$ & $\begin{array}{c}-0.06 \\
{[0.001]}\end{array}$ & $\begin{array}{c}-0.05 \\
{[0.016]}\end{array}$ & $\begin{array}{c}-0.05 \\
{[0.010]}\end{array}$ & $\begin{array}{c}-0.05 \\
{[0.005]}\end{array}$ & $\begin{array}{c}-0.04 \\
{[0.014]}\end{array}$ & $\begin{array}{c}-0.01 \\
{[0.769]}\end{array}$ & $\begin{array}{c}-0.01 \\
{[0.689]}\end{array}$ & $\begin{array}{c}-0.00 \\
{[0.996]}\end{array}$ \\
\hline$c$ & $\begin{array}{c}-0.36 \\
{[0.857]} \\
\end{array}$ & $\begin{array}{c}-0.30 \\
{[0.820]} \\
\end{array}$ & & & $\begin{array}{c}2.98 \\
{[0.000]}\end{array}$ & $\begin{array}{c}5.03 \\
{[0.000]}\end{array}$ & & \\
\hline Obvs. & 646 & 646 & 627 & 627 & 646 & 646 & 627 & 627 \\
\hline $\operatorname{Adj} . R^{2}$ & 0.97 & 0.95 & 0.94 & 0.94 & 0.97 & 0.96 & 0.93 & 0.87 \\
\hline$U$ & & & $\begin{array}{l}8.29 \\
{[0.016]}\end{array}$ & $\begin{array}{l}16.10 \\
{[0.007]}\end{array}$ & & & $\begin{array}{l}8.22 \\
{[0.016]}\end{array}$ & $\begin{array}{c}7.01 \\
{[0.030]}\end{array}$ \\
\hline$H$ & & & $\begin{array}{l}1.91 \\
{[0.167]}\end{array}$ & $\begin{array}{c}9.76 \\
{[0.045]}\end{array}$ & & & $\begin{array}{c}0.29 \\
{[0.589]}\end{array}$ & $\begin{array}{c}0.00 \\
{[0.968]}\end{array}$ \\
\hline$W$ & & & 407.8 & 160.4 & & & 2.78 & 2.04 \\
\hline
\end{tabular}

Notes: All variables are expressed in logs. P-values in brackets. OLS: Ordinary Least Squares.

FE: Fixed Effects. FE-2SLS: Fixed effects using Two Step Least Squares.

$U$ : Under identification test. $H$ : Hansen test. $W$ : Weak identification test. 